\title{
Estimates of Energy Consumption by Building Type and End Use at U.S. Army Installations
}

S.J. Konopacki and H. Akbari Energy and Environment Division August 1996

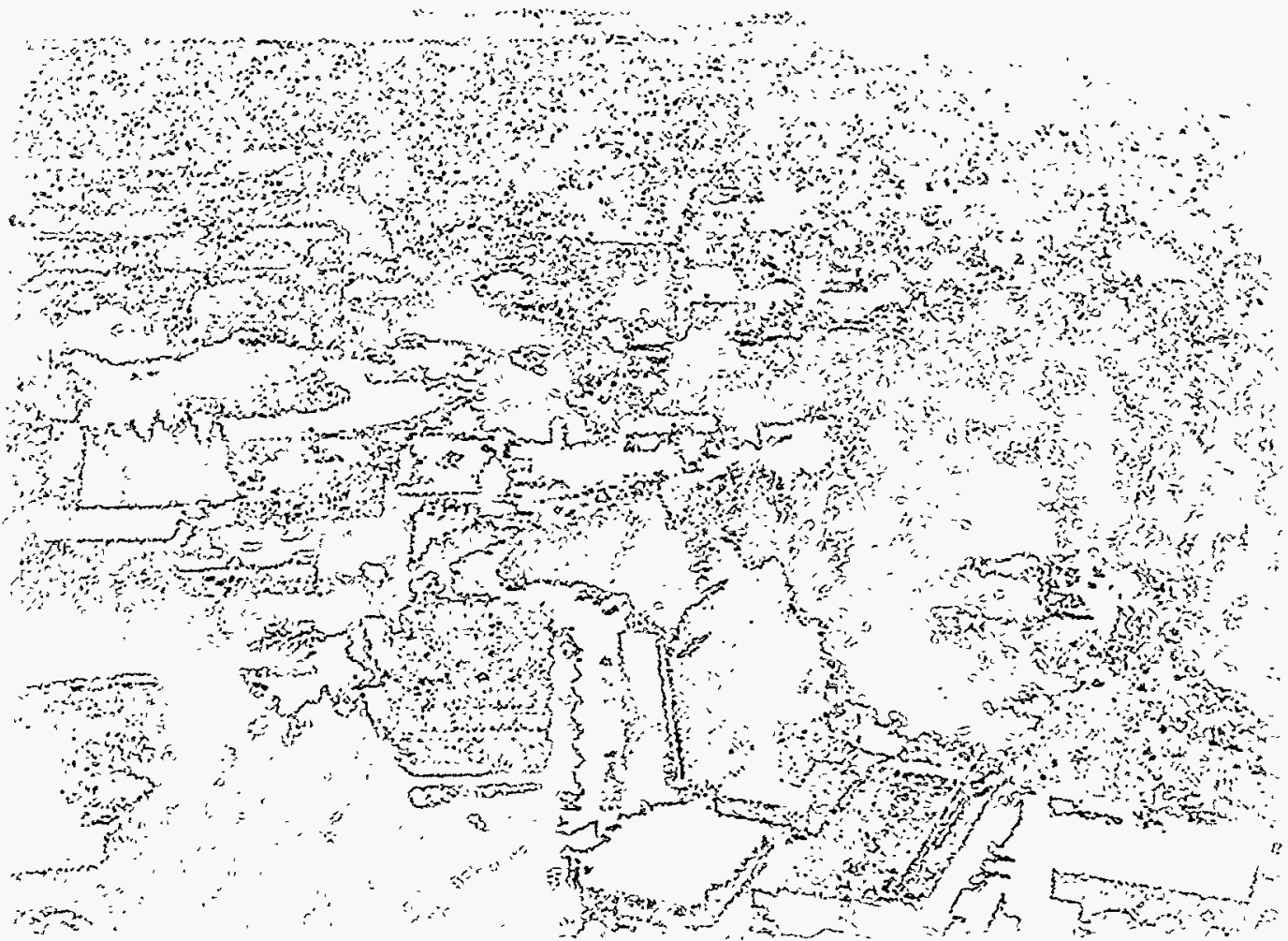




\section{DISCLAIMER}

This document was prepared as an account of work sponsored by the United States Government. While this document is believed to contain correct information, neither the United States Government nor any agency thereof, nor The Regents of the University of California, nor any of their employees, makes any warranty, express or implied, or assumes any legal responsibility for the accuracy, completeness, or usefulness of any information, apparatus, product, or process disclosed, or represents that its use would not infringe privately owned rights. Reference herein to any specific commercial product, process, or service by its trade name, trademark, manufacturer, or otherwise, does not necessarily constitute or imply its endorsement, recommendation, or favoring by the United States Government or any agency thereof, or The Regents of the University of California. The views and opinions of authors expressed herein do not necessarily state or reflect those of the United States Government or any agency thereof, or The Regents of the University of California.

This report has been reproduced directly from the best available copy.

Available to DOE and DOE Contractors

from the Office of Scientific and Technical Information

P.O. Box 62, Oak Ridge, TN 37831

Prices available from (615) $576-8401$

Available to the public from the

National Technical Information Service

U.S. Department of Commerce

5285 Port Royal Road, Springfield, VA 22161

Ernest Orlando Lawrence Berkeley National Laboratory is an equal opportunity employer. 
LBL-38577

UC-000

\title{
Estimates of Energy Consumption by Building Type and End Use at U.S. Army Installations
}

\author{
S. J. Konopacki and H. Akbari \\ Energy and Environment Division \\ Lawrence Berkeley National Laboratory \\ University of California \\ Berkeley, CA 94720
}

\author{
A Report Prepared for \\ Lee DeBaillie and Larry Lister \\ U.S. Army Construction Engineering Research Laboratory \\ P.O. Box 9005 \\ Champaign, IL 61826
}

August 1996

DISTRIBUTION OF THIS DOCURENT IS UNRMITED

This work was supported by a grant from Strategic Environmental Research and Development Program (SERDP) and managed by the U.S. Army Construction Engineering Research Laboratory (CERL) through the U.S. Department of Energy under contract DE-AC03-76SF00098. 


\section{DISCLAIMER}

Portions of this document may be illegible in electronic image products. Images are produced from the best available original document. 


\section{Table of Contents}

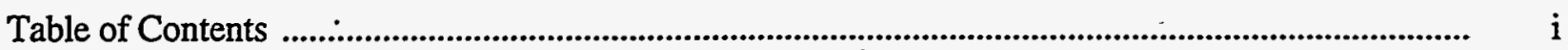

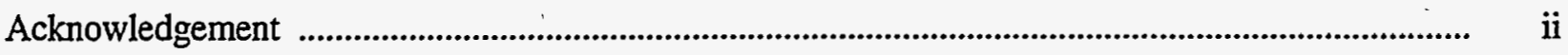

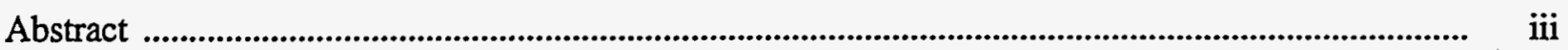

Key to Bar Graphs .............................................................................................................................. iv

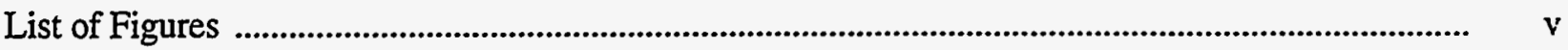

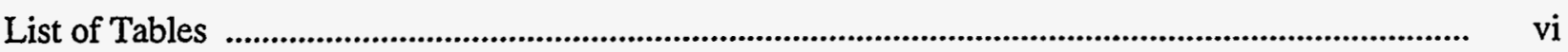

Executive Summary .......................................................................................................................... vii

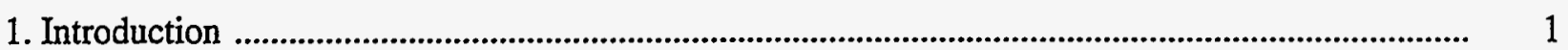

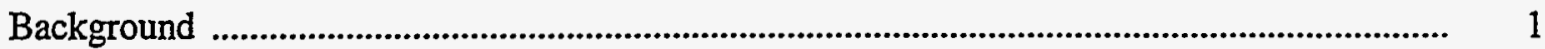

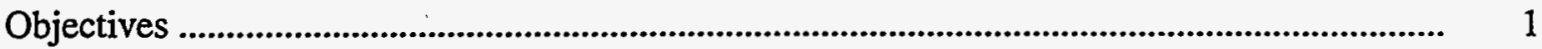

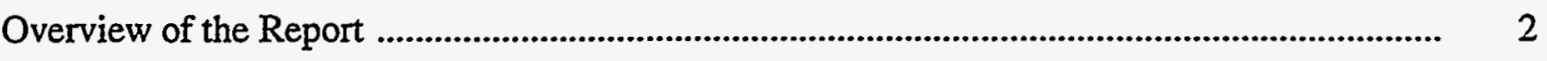

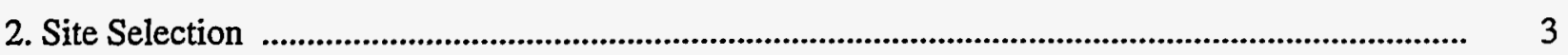

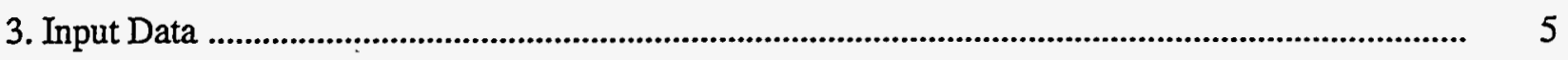

IFS Building Inventory ......................................................................................................... 5

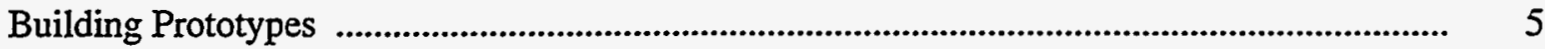

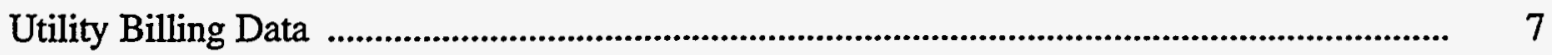

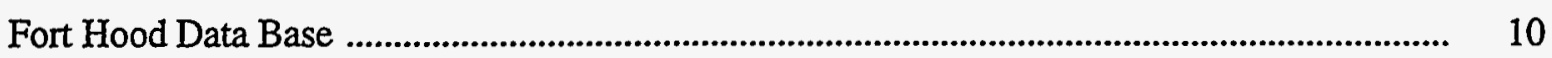

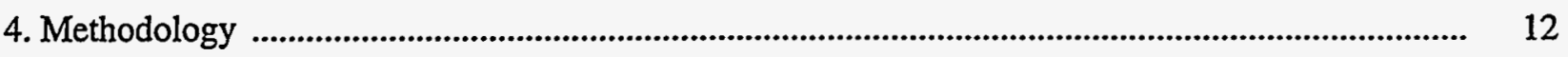

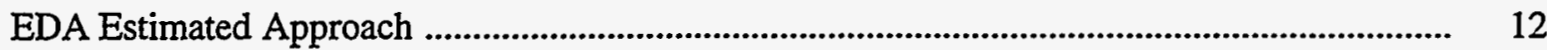

Utility Estimated Approach ..................................................................................................... 13

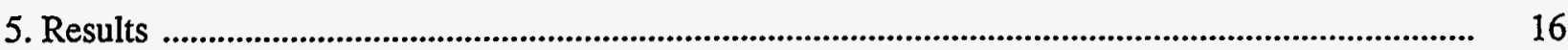

Annual DOE-2 Simulated and EDA Estimated HVAC EUIs ............................................... 16

Annual EDA Estimated Electricity Use ............................................................................... 16

Comparison of Utility Billing Data and EDA Estimates ..................................................... 16

Utility Billing Data Estimated HVAC and Non-HVAC Electricity Use .................................. 27

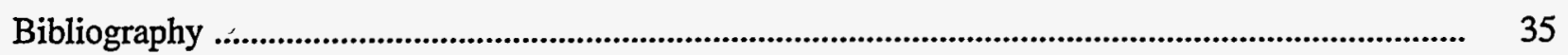




\section{Acknowledgement}

This work was sponsored by the U.S. Army Construction Engineering Research Laboratories (CERL) through the U.S. Department of Energy, Under contract DE-AC0376SF00098. Funding was provided by the Strategic Environmental Research and Development Program (SERDP). Public Law 101-510 established SERDP as a multi-agency program funded through the Department of Defense. SERDP seeks to identify, develop, and demonstrate technologies in the areas of pollution prevention and cleanup, energy and resource conservation and global environmental change. SERDP responds to the environmental requirements of the Department of Defense (DoD) and is undertaken in cooperation with other government agencies, including the Department of Energy (DoE), the National Institutes of Science and Technology (NIST), the National Oceanographic and Atmospheric Administration (NOAA), the National Institutes of Health (NIH), the U.S. Geological Survey (USGS) and the National Aeronautics and Space Administration (NASA). 


\begin{abstract}
This report discusses the application of the Lawrence Berkeley National Laboratory's (LBNL) End-use Disaggregation Algorithm (EDA) to 12 U.S. Army installations nation-wide in order to obtain annual estimates of electricity use for all major building types and end uses. The building types include: barrack, dining hall, gymnasium, administration, vehicle maintenance, hospital, residential, warehouse, and miscellaneous. Up to 8 electric end uses for each building type were considered for EDA application. These electric end uses include space cooling, ventilation (air-handling units, fans, chilled and hot water pumps), cooking, miscellaneous/plugs, refrigeration, exterior and interior lighting, and process loads. Through building simulations, we also obtained estimates of natural gas space heating energy use.

The average electricity use by end use for these 12 installations and Fort Hood are as follows. HVAC, miscellaneous, and indoor lighting end uses consumed the most electricity, with 28,27 , and $26 \%$ of the total use, and $3.8,3.5$, and $3.3 \mathrm{kWh} / \mathrm{ft}^{2}$, respectively. Refrigeration, street lighting, exterior lighting, and cooking end uses consumed $7,7,3$, and $2 \%$ of the total electricity use, and $0.9,0.9,0.4$, and $0.3 \mathrm{kWh} / \mathrm{ft}^{2}$, respectively.
\end{abstract}


Key to Bar Graphs

Installations

$\begin{array}{ll}\text { Fort Dix } & \text { Dix } \\ \text { Fort Belvoir } & \text { Bvr } \\ \text { Fort Bragg } & \text { Brg } \\ \text { Fort Benning } & \text { Bng } \\ \text { Fort Polk } & \text { Plk } \\ \text { Fort Benjamin Harrison } & \text { Bhn } \\ \text { Fort Leonard Wood } & \text { Lwd } \\ \text { Fort Irwin } & \text { Iwn } \\ \text { Fort Sill } & \text { Sll } \\ \text { Yuma Pg } & \text { Yma } \\ \text { Fort Bliss } & \text { Bls } \\ \text { Fort Sam Houston } & \text { Shn } \\ \text { Fort Hood } & \text { Hood }\end{array}$

End Uses

$\begin{array}{ll}\text { Street Lighting } & \text { st lit } \\ \text { Interior Lighting } & \text { in lit } \\ \text { Exterior Lighting } & \text { ex lit } \\ \text { Refrigeration } & \text { refr } \\ \text { Miscellaneous } & \text { misc } \\ \text { Cooking } & \text { cook } \\ \text { HVAC } & \text { hvac }\end{array}$




\section{List of Figures}

Figure

Description

Page

Figure EX-1. 1993 Electricity Consumption Estimates by End Use for 13 U.S. Army Installations (GWh).

viii

Figure EX-2. 1993 Electricity Consumption Estimates by End Use for Average of 13 U.S. Army Installations (\% of Total).

Figure 2-1.

Weather Sites Representing the 12 U.S. Army Installations.

3

1993 Monthly Utility Billing Data for 12 U.S. Army Installations.

8

Figure 3-1(a-1). 1993 Monthly Utility Billing Data for 12 U.S. Army Installations.

9

Figure 4-1.

Two approaches to estimating electricity use at U.S.

Army installations; (1) EDA Estimated and (2) Utility Estimated. .

Figure 4-2. Monthly electrical utility billing data for Fort Benning depicting temperaturedependent HVAC, temperature-independent HVAC, and non-HVAC annual components.

Figure 5-1. 1993 Electricity Use at U.S. Army Installations by Utility Billing Data and EDA Estimates.

Figure 5-2. 1993 Electricity Consumption Estimates by End Use for 13 U.S. Army Installations (GWh).

Figure 5-3. $\quad 1993$ Electricity Consumption Estimates by End Use for 13 U.S. Army Installations $\left(\mathrm{kWh} / \mathrm{ft}^{2}\right)$.

Figure 5-4. 1993 Electricity Consumption Estimates by End Use for 13 U.S. Army Installations (\% of Total).

Figure 5-5. $\quad 1993$ Electricity Consumption Estimates by End Use for 13 U.S. Army Installations, where minimum, maximum, $25 \%$ quartile, $75 \%$ quartile, mean, and median are shown $\left(\mathrm{kWh} / \mathrm{ft}^{2}\right)$.

Figure 5-6. 1993 Electricity Consumption Estimates by End Use for 13 U.S. Army Installations, where minimum, maximum, 25\% quartile, $75 \%$ quartile, mean, and median are shown (\% of Total).

Figure 5-7. 1993 Electricity Consumption Estimates by End Use for Average of 13 U.S. Army Installations (\% of Total). 


\section{List of Tables}

Table

Description

Page

Table 1-1. Project Scope

Table 2-1. U.S. Army Installation Sites and Annual Weather Statistics....................................................... 4

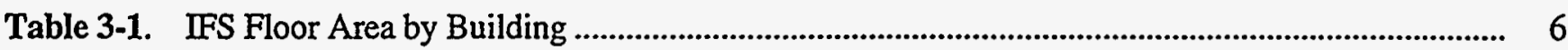

Table 3-2. 1993 Electricity Use at U.S. Army Installations from Utility Billing Data ................................ 7

Table 3-3. Annual DOE-2 Simulated and EDA Reconciled HVAC EUIs at Fort Hood ................................ 11

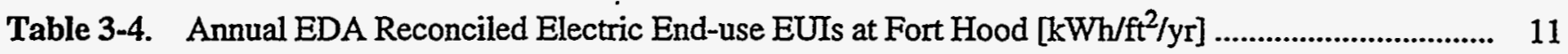

Table 5-1. Annual DOE-2 Simulated and EDA Estimated HVAC EUIs at Fort Dix.................................... 17

Table 5-2. Annual DOE-2 Simulated and EDA Estimated HVAC EUIs at Fort Belvoir................................ 17

Table 5-3. Annual DOE-2 Simulated and EDA Estimated HVAC EUIs at Fort Bragg ................................ 17

Table 5-4. Annual DOE-2 Simulated and EDA Estimated HVAC EUIs at Fort Benning ............................. 18

Table 5-5. Annual DOE-2 Simulated and EDA Estimated HVAC EUIs at Fort Polk .................................. 18

Table 5-6. Annual DOE-2 Simulated and EDA Estimated HVAC EUIs at

Fort Benjamin Harrison

Table 5-7. Annual DOE-2 Simulated and EDA Estimated HVAC EUIs at Fort Leonard Wood.

Table 5-8. Annual DOE-2 Simulated and EDA Estimated HVAC EUIs at Fort Irwin ................................. 19

Table 5-9. Annual DOE-2 Simulated and EDA Estimated HVACEUIs at Fort Sill .................................. 19

Table 5-10. Annual DOE-2 Simulated and EDA Estimated HVAC EUIs at Yuma Pg ................................. 20

Table 5-11. Annual DOE-2 Simulated and EDA Estimated HVAC EUIs at Fort Bliss.................................. 20

Table 5-12. Annual DOE-2 Simulated and EDA Estimated HVAC EUIs at Fort Sam Houston

Table 5-13. Annual EDA Estimated Electricity Use at Fort Dix [GWh/yr] ................................................ 21

Table 5-14. Annual EDA Estimated Electricity Use at Fort Belvoir [GWh/yr] ......................................... 21

Table 5-15. Annual EDA Estimated Electricity Use at Fort Bragg [GWh/yr] ............................................... 21

Table 5-16. Annual EDA Estimated Electricity Use at Fort Benning [GWh/yr].......................................... 22

Table 5-17. Annual EDA Estimated Electricity Use at Fort Polk [GWh/yr] ............................................ 22

Table 5-18. Annual EDA Estimated Electricity Use at Fort Benjamin Harrison [GWh/yr]............................. 22

Table 5-19. Annual EDA Estimated Electricity Use at Fort Leonard Wood [GWh/yr] ................................. 23

Table 5-20. Annual EDA Estimated Electricity Use at Fort Irwin [GWh/yr] ............................................ 23

Table 5-21. Annual EDA Estimated Electricity Use at Fort Sill [GWh/yr] ................................................ 23

Table 5-22. Annual EDA Estimated Electricity Use at Yuma Pg [GWh/yr] ............................................... 24

Table 5-23. Annual EDA Estimated Electricity Use at Fort Bliss [GWh/yr] ............................................... 24

Table 5-24. Annual EDA Estimated Electricity Use at Fort Sam Houston [GWh/yr] ................................... 24

Table 5-25. 1993 Electricity Use at U.S. Army Installations from Utility Billing Data and EDA Estimates

Table 5-26. 1993 Electricity Consumption Estimates by End Use for 13 U.S. Army Installations 


\section{Executive Summary}

In 1993, the U.S. Army Construction Engineering Research Laboratory (CERL) contracted with the Lawrence Berkeley National Laboratory (LBNL) to perform an analysis of existing building and energy use data and obtain energy use intensity (EUI) by end use for major building types in U.S. Army installations. Since most buildings in Army installations are not individually metered, energy use data by building type are scarce. The majority of installations typically have one utility meter measuring electricity and gas energy use for the entire installation, where the electric utility meters usually record consumption at half-hour or one-hour intervals. LBNL was to use their End-use Disaggregation Algorithm (EDA) to disaggregate the hourly whole-installation electricity use into major end uses for major building types.

The objectives of the project were:

- $\quad$ to develop an energy database by building type and by end use for U.S. Army facilities;

- $\quad$ to enhance the DoD energy office's ability to track energy use by end use;

- to establish a vehicle for transferring the analytical methodologies for end-use energy analysis developed at LBNL to CERL.

The project was divided into two phases. In Phase I, the methodology was successfully pilot-tested and a database developed for one Army installation at Fort Hood, Texas. The results of the Phase I study were summarized in an LBNL report prepared for CERL (Akbari and Konopacki, 1995). This report summarizes the results of the Phase II project to obtain EUIs, by end use and major building types, for 12 other Army facilities nation-wide. These 12 facilities are Fort Dix, Fort Belvoir, Fort Bragg, Fort Benning, Fort Polk, Fort Benjamin Harrison, Fort Leonard Wood, Fort Irwin, Fort Sill, Yuma Pg, Fort Bliss, and Fort Sam Houston.

In the Phase I project, we carried out detailed hourly EDA reconciliations for over 12 electricity feeders, which distribute electricity to various areas in the Fort Hood installation. Also, 22 detailed prototypical buildings were developed from a comprehensive survey of selected buildings at Fort Hood. In the current phase (Phase II), because of a lack of detailed quality data for other installations, we decided to achieve the objectives of the project with a hybrid method integrating reconciled end-use data for Fort Hood, a general building type profile in each installation, and monthly and annual electrical utility bills for each installation. Prototypical building characteristics are understood to be uniform across the Army nationwide; therefore, prototypes developed for Fort Hood were applied at all installations with few modifications.

The building types at Army facilities examined in this project cover a wide spectrum of commercial and residential buildings, which include: barrack, dining hall, gymnasium, large administration, small administration (old and new vintage), vehicle maintenance, hospital, residential, warehouse, and miscellaneous. Up to 9 end uses were estimated for each building type, consisting of 8 electric and gas heating; however, only the electric end uses were scaled with Fort Hood EDA results. Space heating EUIs were estimated using the DOE-2 building simulation program. Electric end-use EUIs were also estimated on an installation level using electrical utility billing data. The electric end uses include space cooling, ventilation (air-handling units, fans, chilled and hot water pumps), cooking, miscellaneous/plugs, refrigeration, exterior and interior lighting, and process loads. Street lighting was also estimated for each facility. Hot water consumption data were not available for these installations.

Electricity use estimates for 7 end uses (miscellaneous and process end uses are combined) summed for all building types for an entire installation are presented in Figures EX-1 and EX-2, where Fort Hood estimates are included in the presentation. The average electricity use by end use for these 13 installations (12 installations studied in Phase $I I$ and Fort Hood studied in Phase $I$ ) are as follows. HVAC, 
miscellaneous, and indoor lighting end uses consumed the most electricity, with 28,27 , and $26 \%$ of the total use, and $3.8,3.5$, and $3.3 \mathrm{kWh} / \mathrm{ft}^{2}$, respectively. Refrigeration, street lighting, exterior lighting, and cooking end uses consumed $7,7,3$, and $2 \%$ of the total electricity use, and $0.9,0.9,0.4$, and $0.3 \mathrm{kWh} / \mathrm{ft}^{2}$, respectively.

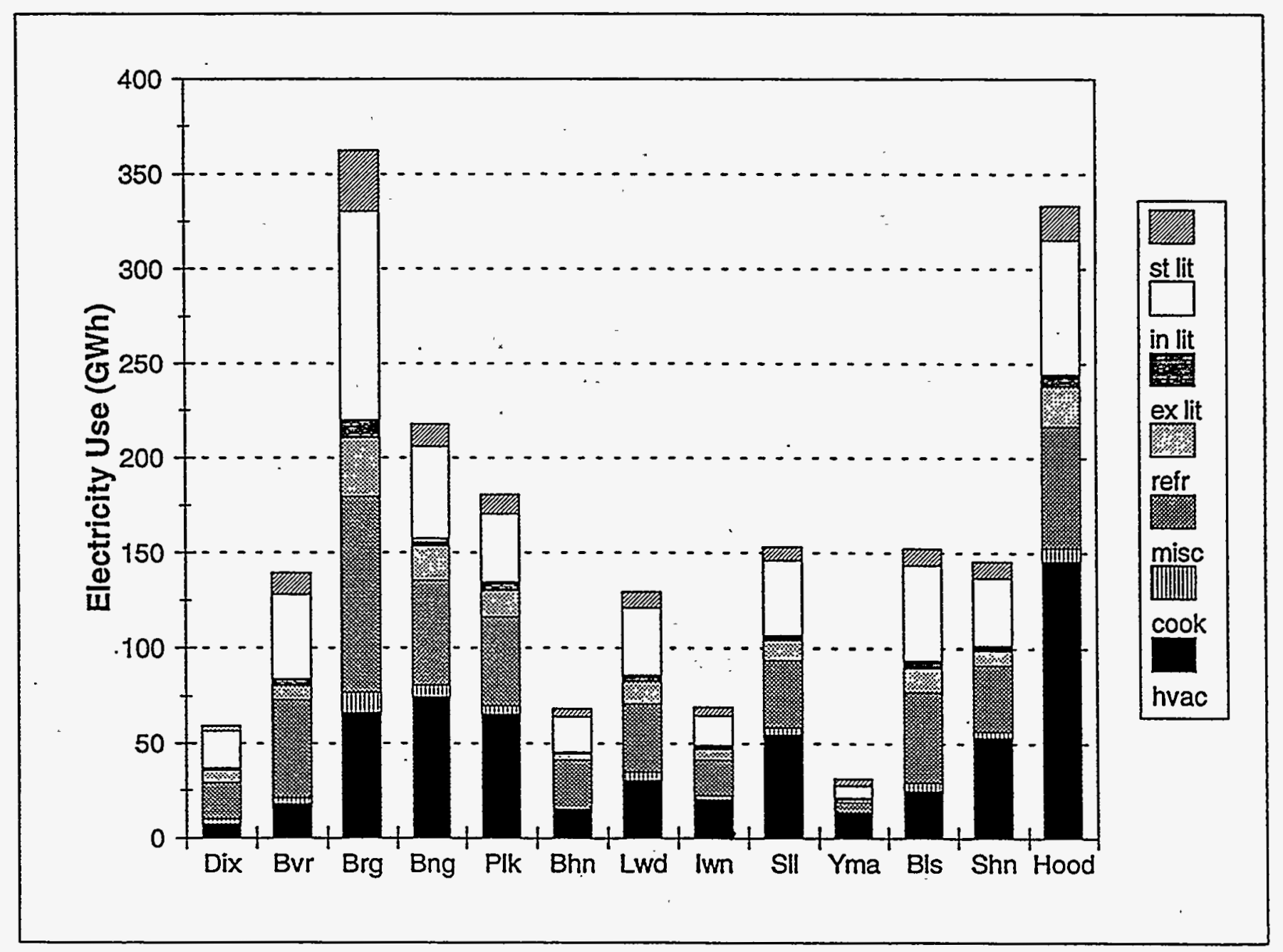

Figure EX-1. 1993 Electricity Consumption Estimates by End Use for 13 U.S. Army Installations (GWh). 
Figure EX-2. 1993 Electricity Consumption Estimates by End Use for Average of 13 U.S. Army Installations (\% of Total).

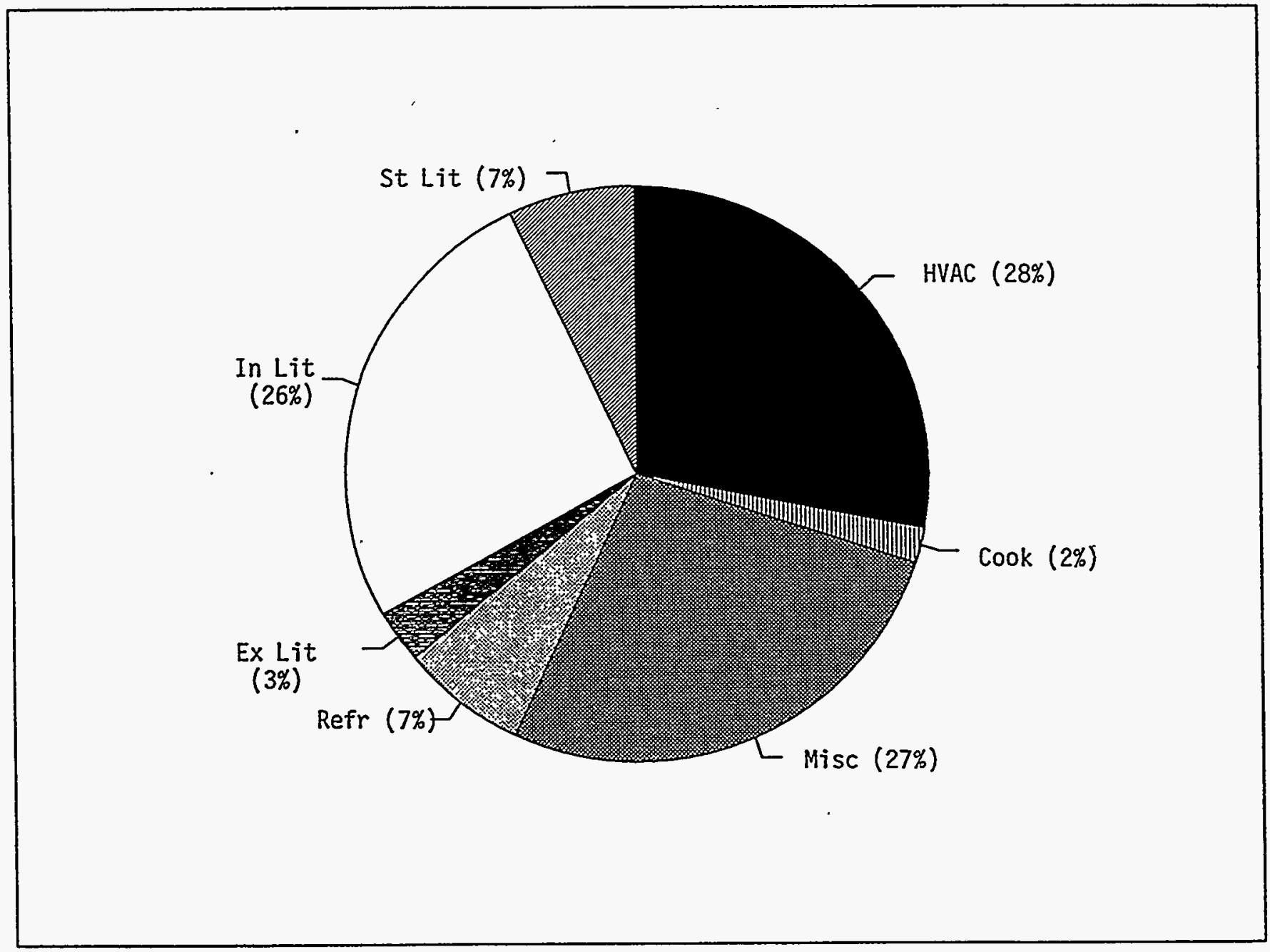




\section{Introduction}

\section{Background}

Defense Energy Program Policy Memorandum (DEPPM) 91-2 requires, through energy efficiency strategies, Department of Defense (DoD) facilities to reduce energy consumption and costs by $20 \%$ from 1985 to 2000. The strategies include both improved operation and maintenance and enhanced energy efficiency measures.

The proper analytical tools, methodologies, and a database of energy consumption by end use for DoD facilities are not readily available to implement energy efficiency programs. The Model Energy Installation Program (MEIP) was developed to prove the concept that DoD could cost-effectively save energy while simultaneously improving both working and living conditions at DoD facilities. Tools are required to perform end-use energy analysis, to predict and forecast future energy scenarios, and to evaluate and recommend cost-effective energy conservation technologies and opportunities.

Historically, the DoD has addressed these objectives by energy audits of the installations and by development of prototypical buildings and assessment of conservation potentials through building energy simulations. Although prototypical studies can result in some general understanding of energy consumption by end use, they must be reconciled against measured energy use for reliable estimates. The End-use Disaggregation Algorithm (EDA) developed at Lawrence Berkeley National Laboratory (LBNL) was designed specifically for this purpose. In EDA, computer simulations are reconciled hourly against measured energy consumption in order to obtain end-use consumption data (Akbari, 1996).

In addition, DoD and government agencies have developed numerous energy analysis tools and energy analysis techniques on a "piecemeal" basis or for specific applications, and have compiled property databases for facilities management (real property databases). This project has drawn upon and brought together these disparate sources of information into an integrated form that can be used for DoD-wide energy end-use characterization.

\section{Objectives}

The objectives of the project were:

- to develop an energy database by building type and by end use for U.S. Army facilities;

- to enhance the DoD energy office's ability to track energy use by end use;

- to establish a vehicle for transferring the analytical methodologies for end-use energy analysis developed at LBNL to the U.S. Army Construction Engineering Research Laboratory (CERL).

The project was divided into two phases. In Phase I, the methodology was successfully pilot-tested and a database developed for one Army installation at Fort Hood, Texas. The results of the Phase I study were summarized in an LBNL report prepared for CERL (Akbari and Konopacki, 1995). This report summarizes the results of the Phase II project to obtain EUIs, by end use and major building types, for 12 other Army facilities nation-wide. These 12 facilities are Fort Dix, Fort Belvoir, Fort Bragg, Fort Benning, Fort Polk, Fort Benjamin Harrison, Fort Leonard Wood, Fort Irwin, Fort Sill, Yuma Pg, Fort Bliss, and Fort Sam Houston.

In the Phase I project, we carried out detailed hourly EDA reconciliations for over 12 electricity feeders, which distribute electricity to various areas in the Fort Hood installation. Also, 22 detailed prototypical buildings were developed from a comprehensive survey of selected buildings at Fort Hood. In the Phase II project, because of a lack of detailed quality data for other installations, it was decided to achieve the 
objectives of the project with a hybrid method integrating reconciled end-use data for Fort Hood, a general building type profile in each installation, and monthly and annual electrical utility bills for each installation. Prototypical building characteristics are understood to be uniform across the Army nation-wide; therefore, prototypes developed for Fort Hood were applied at all installations with few modifications.

The building types at Army facilities examined in this project cover a wide spectrum of commercial and residential buildings, which include: barrack, dining hall, gymnasium, large administration, small administration (old and new vintage), vehicle maintenance, hospital, residential, warehouse, and miscellaneous. Up to 9 end uses were estimated for each building type, consisting of 8 electric and gas heating; however, only the electric end uses were scaled with Fort Hood EDA results. Space heating EUIs were estimated using the DOE-2 building simulation program. Electric end-use EUIs were also estimated on an installation level using electrical utility billing data. The electric end uses include space cooling, ventilation (air-handling units, fans, chilled and hot water pumps), cooking, miscellaneous/plugs, refrigeration, exterior and interior lighting, and process loads. Street lighting was also estimated for each facility. Hot water consumption data were not available for these installations. The scope of the Phase II project is shown in Table 1-1, which presents the building types and end uses examined.

\section{Overview of the Report}

This final report summarizing Phase II activities is organized into five sections. In section 2, we provide an overview of the selected U.S. Army installations. Section 3 reviews input data and analysis performed. In section 4 we discuss the methodology for analysis of data and an approach to end-use data analysis. In section 5 we summarize estimated electricity end-use intensities (EUIs) and electricity use for all major building types and end uses.

Table 1-1. Project Scope

The scope includes 11 building types, 8 electric end uses, and gas space heating. We did not study domestic hot water gas energy use, since these data were unavailable.

\begin{tabular}{|l||c|c|c|c|c|c|c|c|c|}
\hline Building & Cool & Vent & Cook & Misc & Ref & Ex Lit & In Lit & Prcss & Heat $f$ \\
\hline \hline Barrack & $\mathrm{X}$ & $\mathrm{X}$ & $\mathrm{X}$ & $\mathrm{X}$ & $\mathrm{X}$ & $\mathrm{X}$ & $\mathrm{X}$ & & $\mathrm{X}$ \\
Dining Hall & $\mathrm{X}$ & $\mathrm{X}$ & $\mathrm{X}$ & & $\mathrm{X}$ & $\mathrm{X}$ & $\mathrm{X}$ & & $\mathrm{X}$ \\
Gymnasium & $\mathrm{X}$ & $\mathrm{X}$ & & $\mathrm{X}$ & & $\mathrm{X}$ & $\mathrm{X}$ & $\mathrm{X}$ & $\mathrm{X}$ \\
Admin Large & $\mathrm{X}$ & $\mathrm{X}$ & & $\mathrm{X}$ & & $\mathrm{X}$ & $\mathrm{X}$ & & $\mathrm{X}$ \\
Admin Small Old & $\mathrm{X}$ & $\mathrm{X}$ & & $\mathrm{X}$ & & $\mathrm{X}$ & $\mathrm{X}$ & & $\mathrm{X}$ \\
Admin Small New & $\mathrm{X}$ & $\mathrm{X}$ & & $\mathrm{X}$ & & $\mathrm{X}$ & $\mathrm{X}$ & & $\mathrm{X}$ \\
Vehicle Maintenance & $\mathrm{X}$ & $\mathrm{X}$ & & $\mathrm{X}$ & & $\mathrm{X}$ & $\mathrm{X}$ & $\mathrm{X}$ & $\mathrm{X}$ \\
Hospital & $\mathrm{X}$ & $\mathrm{X}$ & $\mathrm{X}$ & $\mathrm{X}$ & $\mathrm{X}$ & $\mathrm{X}$ & $\mathrm{X}$ & & $\mathrm{X}$ \\
Residential & $\mathrm{X}$ & $\mathrm{X}$ & $\mathrm{X}$ & $\mathrm{X}$ & $\mathrm{X}$ & $\mathrm{X}$ & $\mathrm{X}$ & & $\mathrm{X}$ \\
Warehouse & $\mathrm{X}$ & $\mathrm{X}$ & & $\mathrm{X}$ & & $\mathrm{X}$ & $\mathrm{X}$ & & $\mathrm{X}$ \\
Miscellaneous & $\mathrm{X}$ & $\mathrm{X}$ & $\mathrm{X}$ & $\mathrm{X}$ & $\mathrm{X}$ & $\mathrm{X}$ & $\mathrm{X}$ & & $\mathrm{X}$ \\
\hline
\end{tabular}

$\doteqdot$ Space heating is a gas end-use and was estimated with DOE-2 simulations. 


\section{Site Selection}

The Army has more than 90 major installations nation-wide of mission types, Forces Command (FORSCOM), Military District of Washington (MDW), Training and Doctrine Command (TRADOC), and Army Material Command (AMC). FORSCOM are installations with combat-ready forces. The mission of MDW facilities are to provide general oversight and administration. In a TRADOC base, forces are trained for combat-readiness. The purpose of an AMC facility is weapons production and storage and proving grounds for testing.

Twelve installations were selected for analysis in this project and the criteria for choosing them were:

- they should represent all four major mission types;

- they should include the influence of building types and scheduling particular to each mission type;

- they should be larger bases that include most major building types;

- they should represent all major climate regions with emphasis on regions with high concentrations of Army installations.

The selected installations and weather sites used for DOE-2 simulations are shown in Table 2-1. The weather locations were the closest available and are illustrated in Figure 2-1. The weather tapes were of the Typical Meteorological Year (TMY) format for Philadelphia, St. Louis, Barstow, and Needles, and of the Weather Year for Energy Computation (WYEC) format for Washington DC, Raleigh, Atlanta, Lake Charles, Indianapolis, Oklahoma City, El Paso, and San Antonio.

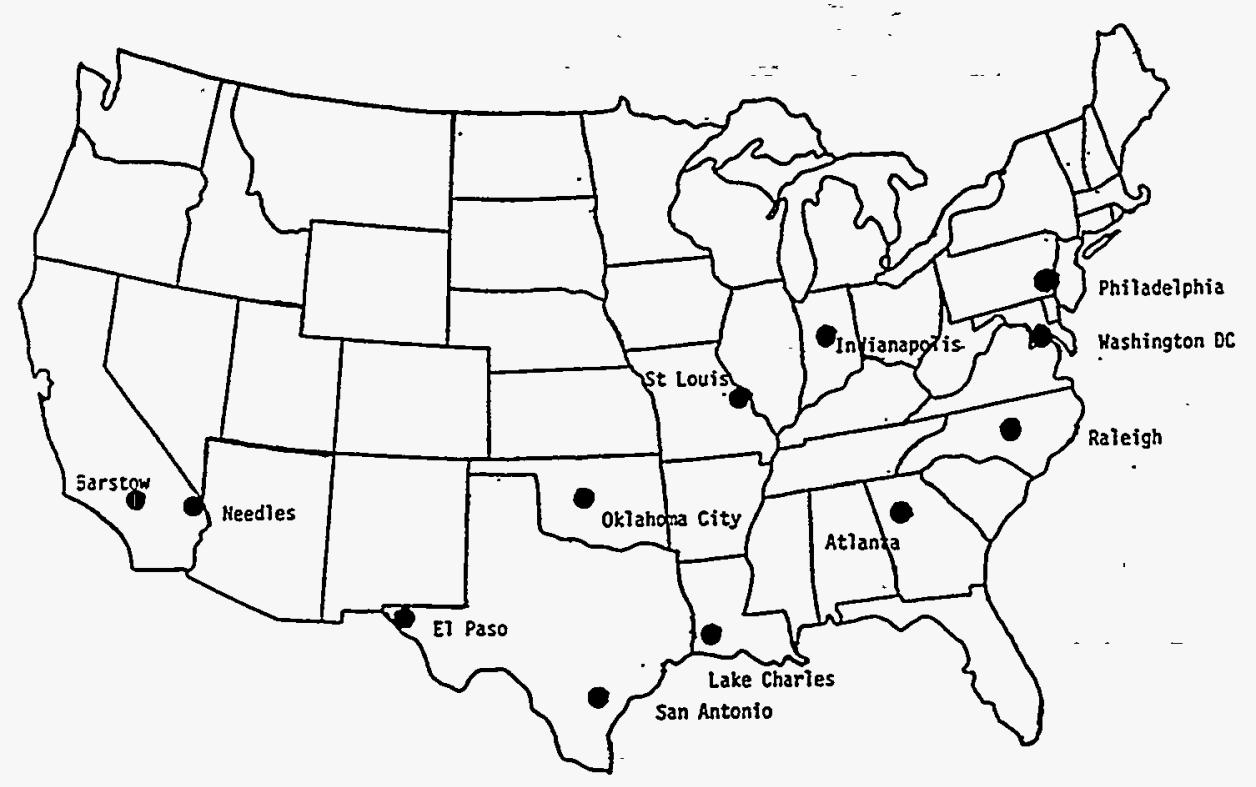

Figure 2-1. Weather Sites Representing the 12 U.S. Army Installations, where the northeast, midwest, southeast, and southwest regions represented areas with a high concentration of installations. Fort Lewis near Seattle was to represent the northwest region, however the quality of electrical utility billing data was inadequate. 
Table 2-1. U.S. Army Installation Sites and Annual Weather Statistics

(HDH $=$ Heating Degree Hours, $\mathrm{CDH}=$ Cooling Degree Hours, $\mathrm{LEH}=$ Latent Enthalpy Hours)

\begin{tabular}{|c|c|c|c|c|c|c|}
\hline \multicolumn{3}{|c|}{ Installation Site } & \multicolumn{4}{|c|}{ Weather Site } \\
\hline Name & Type & Location & Location & $\begin{array}{c}\mathrm{HDH} / 24 \\
\text { (base } 65^{\circ} \mathrm{F} \text { ) }\end{array}$ & $\begin{array}{c}\mathrm{CDH} / 24 \\
\text { (base } 65^{\circ} \mathrm{F} \text { ) }\end{array}$ & $\begin{array}{c}\text { LEH } \\
\text { (btul//lb dry air) }\end{array}$ \\
\hline Northeast & & & & & & \\
\hline $\begin{array}{l}\text { Fort Dix } \\
\text { Southeast }\end{array}$ & FORSCOM & Wrightstown, NJ & Philadelphia, PA & 5113 & 1185 & 3668 \\
\hline Fort Bclvoir & MDW & Springfield, VA & Washington DC & 4410 & 1494 & 3734 \\
\hline Fort Bragg & FORSCOM & Fayctteville, NC & Raleigh, NC & 3779 & 1507 & 4790 \\
\hline Fort Benning & TRADOC & Columbus, GA & Atlanta, GA & 3215 & 1602 & 4931 \\
\hline Fort Polk & FORSCOM & Leesville, LA & Láke Charles, LA & 1718 & 2686 & $t$ \\
\hline Midwest & & & & & & \\
\hline Fort Benjamin Harrison & TRADOC & Indianapolis, IN & Indianapolis, IN & 5831 & 1133 & 2745 \\
\hline Fort Leonard Wood & TRADOC & Waynesville, MO & St Louis, MO & 5069 & 1588 & 6210 \\
\hline California & & & & & & \\
\hline Fort Irwin & FORSCOM & Barstow, CA & Barstow, CA & 2751 & 3213 & $\ddagger$ \\
\hline Southwest & & 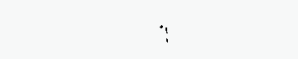 & & & & \\
\hline Fort Sill & TRADOC & Lawton, OK & Oklahoma City, OK & 4036 & 2019 & 5001 \\
\hline Yuma Pg & AMC & Yuma, $A Z$ & Needles, CA & 1446 & 4613 & $\doteqdot$ \\
\hline Fort Bliss & TRADOC & El Paso, TX & El Paso, TX & 2866 & 2429 & 70 \\
\hline Fort Sam Houston & FORSCOM & San Antonio, TX & San Antonio, TX & 1805 & 2913 & 12953 \\
\hline
\end{tabular}

† Data were unavailable: New Orleans 17754 and Shreveport, LA 12312

† Data were unavailable: Bakersfield, CA 15 


\section{Input Data}

There were four sources of input data; IFS building inventory data, building prototypes, electrical utility billing data, and Fort Hood data. The Fort Hood data included DOE-2 simulated HVAC EUIs and EDA reconciled HVAC and non-HVAC EUIs by building type.

\section{IFS Building Inventory}

The IFS building inventory data included building category code, floor area, year of construction, HVAC system type, and electricity connection status. These data were categorized into the 11 building types identified in Table 1-1 and 4 additional types (non-building, utility, pump, and fuel station) based on the category code, floor area, and year of construction. Non-building, utility, pump, and fuel station buildings were grouped into the miscellaneous building type for the remainder of the analyses. Data identifying the HVAC system type for most of the entries were either missing (represented by an " $\mathrm{X}$ ") or indicated no cooling (also represented by an "X"), which provided for unreliable estimates of air-conditioning system types and saturations. Each of the building types were represented by all 12 Army bases with the exception of Fort Irwin (no large administration) and Yuma Pg (no large administration or hospital). Building types and building floor area of each installation are listed in Table 3-1. Buildings listed in IFS as without electrical connection were not included in Table 3-1 and the subsequent analyses.

\section{Building Prototypes}

In Phase II, data identifying building characteristics were scarce. The only source was the IFS building inventory data base, which listed category code, floor area, and year of construction. Information identifying HVAC system type was not available. Therefore, the 22 building types from Phase I were condensed into the 11 building types identified in Table 1-1. The small-old (new vintage) administration prototype with a packaged HVAC system from Phase I represented all small-old (new) administration buildings in Phase II. The hammerhead barrack represented all barracks. The large vehicle maintenance with a packaged HVAC system represented all vehicle maintenance buildings and hangars. The detached residence represented all residences. The warehouse with a packaged HVAC system represented all warehouses. Building prototypical characteristics are summarized in detail in Akbari and Konopacki (1995).

The building prototypes for Fort Hood differed from those of the other installations only in HVAC system characteristics. In Fort Hood, cooling was available from April 11 through October 22 and heating for the rest of the year; where in the other installations, cooling was available during temperature-dependent months as defined in Utility Billing Data in this section. Also, the temperature controlled economizer was replaced with an enthalpic control device to better model outside-air control in humid climates, and DOE-2 was allowed to automatically size HVAC equipment. 
Table 3-1. IFS Building Inventory Data Floor Area by Building Type

\begin{tabular}{|c|c|c|c|c|c|c|c|c|c|c|c|c|}
\hline \multirow[b]{2}{*}{ Building Type } & \multicolumn{2}{|c|}{ Fort Dix } & \multicolumn{2}{|c|}{ Fort Belvoir } & \multicolumn{2}{|c|}{ Fort Bragg } & \multicolumn{2}{|c|}{ Fort Benning } & \multicolumn{2}{|c|}{ Fort Folk } & \multicolumn{2}{|c|}{ Fort Harrison } \\
\hline & Number & $\begin{array}{c}\text { Floor Area } \\
\mathrm{kft}^{2}\end{array}$ & Number & $\begin{array}{c}\text { Floor Area } \\
\mathrm{kft}^{2}\end{array}$ & Number & $\begin{array}{c}\text { Floor Area } \\
\mathrm{kft}^{2}\end{array}$ & Number & $\begin{array}{c}\text { Floor Area } \\
\mathrm{kft}^{2}\end{array}$ & Number & $\begin{array}{c}\text { Floor Area } \\
\mathrm{kft}^{2}\end{array}$ & Number & $\begin{array}{c}\text { Floor Area } \\
\mathrm{kft}^{2}\end{array}$ \\
\hline $\begin{array}{l}\text { Barrack } \\
\text { Dining Hall } \\
\text { Gymnasium } \\
\text { Admin. Large } \\
\text { Admin. Small Old } \\
\text { Admin. Small New } \\
\text { Vehicle Maintenance } \\
\text { Hospital } \\
\text { Residential } \\
\text { Warehouse } \\
\text { Miscellaneous } \\
\text { Non-Building } \\
\text { Utility } \\
\text { Pump } \\
\text { Fuel Station }\end{array}$ & $\begin{array}{r}67 \\
76 \\
2 \\
6 \\
147 \\
62 \\
45 \\
1 \\
600 \\
188 \\
40 \\
253 \\
79 \\
32 \\
14\end{array}$ & $\begin{array}{r}1961 \\
181 \\
38 \\
320 \\
825 \\
118 \\
301 \\
427 \\
1882 \\
606 \\
430 \\
1624 \\
61 \\
9 \\
2\end{array}$ & $\begin{array}{r}33 \\
4 \\
4 \\
15 \\
174 \\
13 \\
81 \\
1 \\
753 \\
180 \\
43 \\
60 \\
32 \\
11 \\
5\end{array}$ & $\begin{array}{r}629 \\
119 \\
68 \\
1584 \\
1157 \\
83 \\
1048 \\
260 \\
3048 \\
909 \\
520 \\
74 \\
26 \\
5 \\
2\end{array}$ & $\begin{array}{r}308 \\
76 \\
12 \\
19 \\
809 \\
205 \\
237 \\
1 \\
2225 \\
434 \\
110 \\
848 \\
116 \\
26 \\
47\end{array}$ & $\begin{array}{r}4703 \\
488 \\
218 \\
1364 \\
3510 \\
1216 \\
2615 \\
413 \\
7387 \\
1855 \\
944 \\
576 \\
129 \\
21 \\
12\end{array}$ & $\begin{array}{r}161 \\
48 \\
2 \\
18 \\
355 \\
46 \\
123 \\
1 \\
1376 \\
345 \\
80 \\
387 \\
134 \\
15 \\
27\end{array}$ & $\begin{array}{r}4961 \\
462 \\
61 \\
1409 \\
1877 \\
397 \\
1225 \\
393 \\
6039 \\
967 \\
796 \\
443 \\
95 \\
7 \\
24\end{array}$ & $\begin{array}{r}239 \\
50 \\
2 \\
2 \\
278 \\
119 \\
162 \\
1 \\
1293 \\
345 \\
75 \\
140 \\
145 \\
40 \\
19\end{array}$ & $\begin{array}{r}2414 \\
226 \\
50 \\
70 \\
1144 \\
979 \\
1261 \\
367 \\
8508 \\
939 \\
585 \\
66 \\
57 \\
10 \\
5\end{array}$ & $\begin{array}{r}30 \\
3 \\
3 \\
11 \\
44 \\
7 \\
11 \\
1 \\
89 \\
62 \\
38 \\
243 \\
7 \\
2 \\
2\end{array}$ & $\begin{array}{r}881 \\
54 \\
49 \\
1882 \\
308 \\
29 \\
77 \\
105 \\
593 \\
298 \\
277 \\
28 \\
26 \\
4 \\
0\end{array}$ \\
\hline Total & 1612 & 8785 & 1409 & 9532 & 5473 & 25451 & 3118 & 19156 & 2910 & 16681 & 553 & 4611 \\
\hline \multirow[b]{2}{*}{ Building Type } & \multicolumn{2}{|c|}{ Fort Wood } & \multicolumn{2}{|c|}{ Fort Irwin } & \multicolumn{2}{|c|}{ Fort Sill } & \multicolumn{2}{|c|}{ Yuma Pg } & \multicolumn{2}{|c|}{ Fort Bliss } & \multicolumn{2}{|c|}{ Fort Houston } \\
\hline & Number & $\begin{array}{c}\text { Floor Area } \\
\mathrm{kft}^{2}\end{array}$ & Number & $\begin{array}{c}\text { Floor Area } \\
\mathrm{kft}^{2}\end{array}$ & Number & $\begin{array}{c}\text { Floor Area } \\
\mathrm{kft}^{2}\end{array}$ & Number & $\begin{array}{c}\text { Floor Area } \\
\mathrm{kft}^{2}\end{array}$ & Number & $\begin{array}{c}\text { Floor Area } \\
\mathrm{kft}^{2}\end{array}$ & Number & $\begin{array}{c}\text { Floor Area } \\
\mathrm{kft}^{2}\end{array}$ \\
\hline $\begin{array}{l}\text { Barrack } \\
\text { Dining Hall } \\
\text { Gymnasium } \\
\text { Admin. Large } \\
\text { Admin. Small Old } \\
\text { Admin. Small New } \\
\text { Vehicle Maintenance } \\
\text { Hospital } \\
\text { Residential } \\
\text { Warehouse } \\
\text { Miscellaneous } \\
\text { Non-Building } \\
\text { Utility } \\
\text { Pump } \\
\text { Fuel Station }\end{array}$ & $\begin{array}{r}149 \\
26 \\
2 \\
11 \\
269 \\
89 \\
54 \\
1 \\
1149 \\
166 \\
110 \\
74 \\
77 \\
6 \\
11\end{array}$ & $\begin{array}{r}2405 \\
339 \\
101 \\
544 \\
1136 \\
452 \\
554 \\
404 \\
3556 \\
603 \\
478 \\
679 \\
72 \\
9 \\
1\end{array}$ & $\begin{array}{r}64 \\
14 \\
1 \\
0 \\
97 \\
120 \\
69 \\
1 \\
818 \\
102 \\
154 \\
33 \\
40 \\
12 \\
3\end{array}$ & $\begin{array}{r}732 \\
95 \\
23 \\
0 \\
246 \\
607 \\
504 \\
64 \\
3183 \\
413 \\
15 \\
286 \\
18 \\
5 \\
1 .\end{array}$ & $\begin{array}{r}198 \\
40 \\
2 \\
21 \\
381 \\
163 \\
107 \\
2 \\
820 \\
325 \\
272 \\
93 \\
79 \\
17 \\
22\end{array}$ & $\begin{array}{r}3277 \\
387 \\
62 \\
1535 \\
2120 \\
588 \\
1072 \\
498 \\
2356 \\
1103 \\
270 \\
778 \\
107 \\
8 \\
7\end{array}$ & $\begin{array}{r}12 \\
1 \\
1 \\
0 \\
41 \\
9 \\
21 \\
0 \\
197 \\
87 \\
71 \\
24 \\
21 \\
8 \\
2\end{array}$ & $\begin{array}{r}118 \\
13 \\
12 \\
0 \\
204 \\
50 \\
96 \\
0 \\
436 \\
163 \\
117 \\
127 \\
7 \\
2 \\
0\end{array}$ & $\begin{array}{r}183 \\
36 \\
5 \\
18 \\
449 \\
70 \\
93 \\
2 \\
2197 \\
214 \\
110 \\
92 \\
37 \\
24 \\
21\end{array}$ & $\begin{array}{r}2856 \\
271 \\
154 \\
1010 \\
2651 \\
266 \\
1231 \\
675 \\
4359 \\
1028 \\
208 \\
856 \\
26 \\
21 \\
6\end{array}$ & $\begin{array}{r}54 \\
7 \\
4 \\
12 \\
212 \\
21 \\
19 \\
6 \\
605 \\
61 \\
276 \\
47 \\
48 \\
3 \\
2\end{array}$ & $\begin{array}{r}1726 \\
189 \\
92 \\
1100 \\
1279 \\
131 \\
316 \\
636 \\
1746 \\
1082 \\
151 \\
643 \\
49 \\
10 \\
4\end{array}$ \\
\hline Total & 2194 & 11333 & 1528 & 6192 & 2542 & 14168 & 495 & 1345 & 3551 & 15618 & 1377 & 9154 \\
\hline
\end{tabular}




\section{Utility Billing Data}

The monthly electrical utility data for 1993 are plotted in Figures 3-1(a) through 3-1(l) for 12 U.S. Army facilities. These data illustrated the temperature-dependent load behavior of each facility, where prototypical HVAC seasonal schedules were derived. Observed in these plots were two distinct regions, winter and summer. The winter load was defined as temperature-independent. The summer was characterized by a component of temperature-dependent load behavior (air-conditioning use) and of temperatureindependent load behavior. The temperature-dependent component was assumed to be all airconditioning use, and the temperature-independent component included air-conditioning and fans and pumps attributed to space heating, as well as non-HVAC end uses. The information derived from the utility billing data are displayed in Table 3-2, which included temperature-dependent HVAC, temperature-independent HVAC, temperature-independent non-HVAC, and months of loads with temperature-dependent behavior. See section 4, Utility Estimated Approach, for further discussion of these data.

Table 3-2. 1993 Electricity Use at U.S. Army Installations from Utility Billing Data

\begin{tabular}{|c|c|c|c|c|c|c|}
\hline \multirow[b]{2}{*}{ Installation } & \multicolumn{3}{|c|}{ HVAC } & \multirow{2}{*}{$\begin{array}{c}\text { Non-HVAC } \\
\text { (GWh) }\end{array}$} & \multirow{2}{*}{$\begin{array}{l}\text { Total } \\
\text { (GWh) }\end{array}$} & \multirow{2}{*}{$\begin{array}{l}\text { Months of Loads w/ } \\
\text { Temperature-Dependent } \\
\text { Behavior }\end{array}$} \\
\hline & $\begin{array}{l}\text { Temperature- } \\
\text { Dependent } \\
\text { (GWh) }\end{array}$ & $\begin{array}{c}\text { Temperature- } \\
\text { Independent } \\
\text { (GWh) }\end{array}$ & $\begin{array}{l}\text { Total } \\
\text { (GWh) }\end{array}$ & & & \\
\hline Fort Dix & 4.4 & 3.2 & 7.6 & 54.9 & 62.5 & Jul, Aug, Sep \\
\hline Fort Belvoir & 10.4 & 7.6 & 18.0 & 129.3 & 147.3 & Jul, Aug, Sep \\
\hline Fort Bragg & 38.4 & 28.0 & 66.4 & 315.0 & 381.4 & Jun, Jul, Aug, Sep, Oct \\
\hline Fort Benning & 43.2 & 31.5 & 74.7 & 153.9 & 228.6 & Jun, Jul, Aug, Sep, Oct \\
\hline Fort Polk & 37.9 & 27.7 & 65.6 & 124.9 & 190.5 & Jun, Jul, Aug, Sep, Oct, Nov \\
\hline Fort Benjamin Harrison & 8.2 & 6.0 & 14.2 & 57.8 & 72.0 & Jun, Jul, Aug, Sep \\
\hline Fort Leonard Wood & 17.6 & 12.8 & 30.4 & 105.9 & 136.3 & Jun, Jul, Aug, Sep \\
\hline Fort Irwin & 11.8 & 8.6 & 20.4 & 52.4 & 72.8 & May, Jun, Jul, Aug, Sep, Oct \\
\hline Fort Sill & 31.6 & 23.1 & 54.7 & 106.2 & 160.9 & May, Jun, Jul, Aug, Sep \\
\hline Yuma Pg & 7.7 & 5.6 & 13.3 & 19.6 & 32.9 & May, Jun, Jul, Aug, Sep, Oct \\
\hline Fort Bliss & 14.4 & 10.5 & 24.9 & 135.3 & 160.2 & Jun, Jul, Aug, Sep \\
\hline Fort Sam Houston & 30.9 & 22.6 & 53.5 & 99.6 & 153.1 & May, Jun, Jul, Aug, Sep, Oct \\
\hline
\end{tabular}


Figure 3-1(a-f). 1993 Monthly Utility Billing Data for 12 U.S. Army Installations.
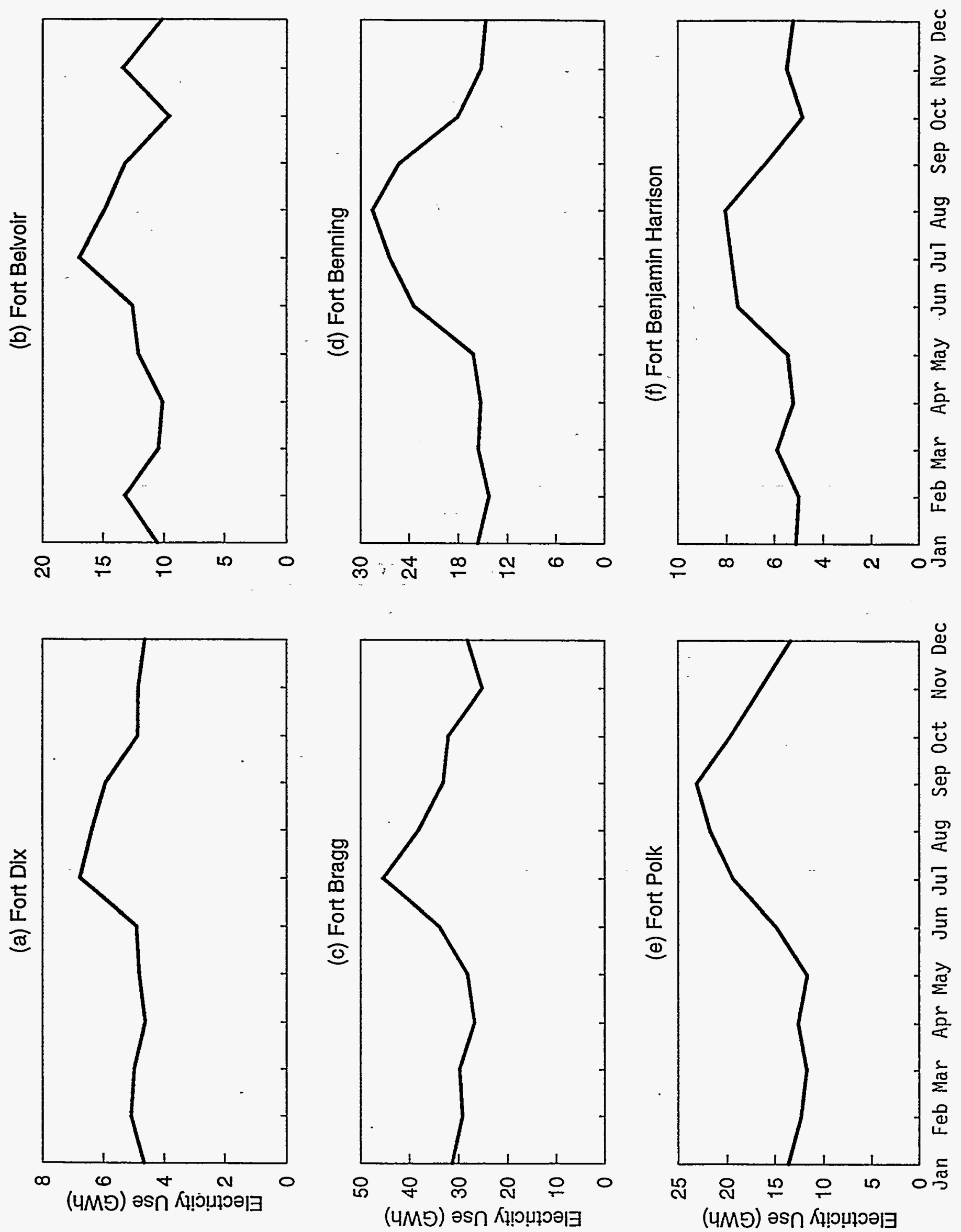
Figure 3-1(g-l). 1993 Monthly Utility Billing Data for 12 U.S. Army Installations.
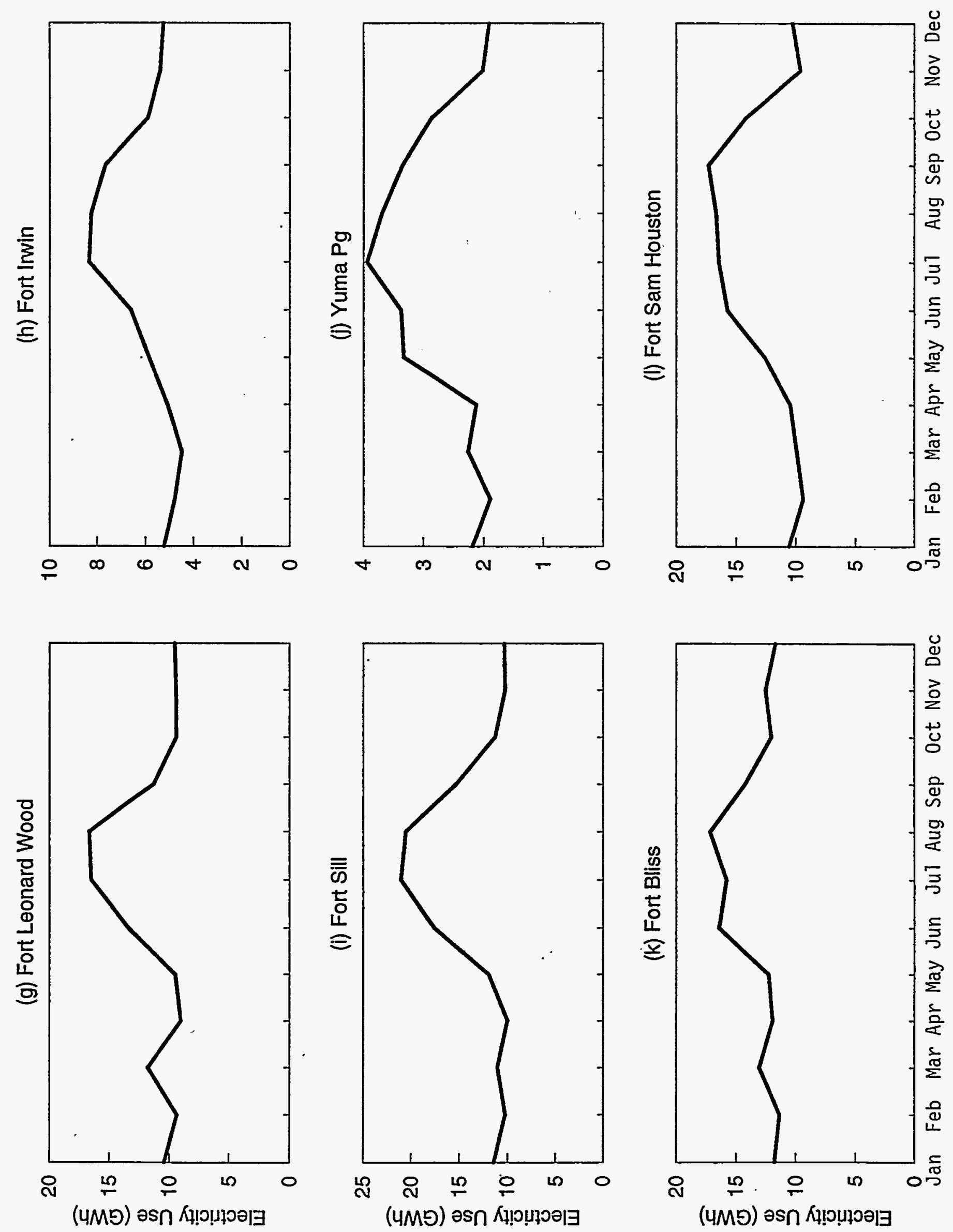


\section{Fort Hood Data Base}

Data from Phase I analyses at Fort Hood include annual DOE-2 simulated HVAC EUIs and EDA reconciled HVAC and Non-HVAC electric EUIs, and the ratio of EDA reconciled temperature-independent to temperature-dependent HVAC. The 22 prototypes developed at Fort Hood were condensed into the 11 building types identified in Table 1-1, since regional prototypical characteristics were not available.

Annual DOE-2 simulated HVAC EUIs and EDA reconciled HVAC and Non-HVAC electric EUIs derived at Fort Hood are shown in Tables 3-3 and 3-4. These were obtained by weighting together by floor area similar building types (hammer head, rolling pin, modular, and small barrack were weighted into a single barrack type; packaged and central system type small administration into a single small administration type; small and large vehicle maintenance and hangar into a single vehicle maintenance type; detached, two-plex, and four-plex residential into a single residential type; packaged and non-cooled warehouse into a single warehouse type). The non-HVAC EUIs (cooking, miscellaneous/plug, refrigeration, exterior and interior lighting, and process) were assumed to be uniform nation-wide. The Fort Hood Data base for 22 prototypes can be found in Akbari and Konopacki (1995). The ratio of EDA reconciled temperature-independent to temperature-dependent HVAC annual electricity use was 0.73 at Fort Hood. 
Table 3-3. Annual DOE-2 Simulated and EDA Reconciled HVAC EUTs at Fort Hood

\begin{tabular}{|l||c|c|c||c|c|}
\hline \multicolumn{1}{|c||}{ Building } & \multicolumn{3}{c||}{ DOE-2 } & \multicolumn{2}{c|}{ EDA } \\
\cline { 2 - 6 } & $\begin{array}{c}\text { Cooling } \\
\mathrm{kWh} / \mathrm{ft}^{2}\end{array}$ & $\begin{array}{c}\text { Ventilation } \\
\mathrm{kWh} / \mathrm{ft}^{2}\end{array}$ & $\begin{array}{r}\text { Heating } \\
\mathrm{kBtu} / \mathrm{ft}^{2}\end{array}$ & $\begin{array}{c}\text { Cooling } \\
\mathrm{kWh} / \mathrm{ft}^{2}\end{array}$ & $\begin{array}{c}\text { Ventilation } \\
\mathrm{kWh} / \mathrm{ft}^{2}\end{array}$ \\
\hline \hline Barrack & 3.51 & 1.16 & 3.80 & 3.83 & 2.07 \\
Dining Hall & 5.62 & 0.96 & 7.35 & 5.28 & 2.09 \\
Gymnasium & 1.59 & 0.69 & 28.59 & 2.32 & 0.90 \\
Administration Large & 4.29 & 3.79 & 0.18 & 2.85 & 3.18 \\
Administration Small Old & 6.68 & 3.18 & 20.29 & 5.82 & 4.17 \\
Administration Small New & 4.93 & 2.42 & 11.87 & 5.73 & 2.54 \\
Vehicle Maintenance & 0.47 & 0.23 & 29.44 & 0.49 & 0.57 \\
Hospital & 8.13 & 2.83 & 13.28 & 6.24 & 1.72 \\
Residential & 5.71 & 0.45 & 12.63 & 4.98 & 0.41 \\
Warehouse & 0.70 & 0.29 & 12.39 & 1.16 & 0.34 \\
Miscellaneous & 4.50 & 1.19 & 5.62 & 4.64 & 0.84 \\
\hline
\end{tabular}

Table 3-4. Annual EDA Reconciled Electric End-use EUIs at Fort Hood [kWh/ft $\left.{ }^{2} / \mathrm{yr}\right]$

\begin{tabular}{|l||c|c|c|c|c|c|c|c||r|}
\hline Prototype & Cool & Vent & Cook & Misc & Ref & Ex Lit & In Lit & Prcss & Total \\
\hline \hline Barrack & 3.83 & 2.07 & 0.30 & 1.55 & 2.05 & 0.16 & 1.74 & - & 11.70 \\
Dining Hall & 5.28 & 2.09 & 5.94 & - & 4.60 & 0.13 & 3.69 & - & 21.73 \\
Gymnasium & 2.32 & 0.90 & - & 0.60 & - & 0.19 & 5.85 & 0.09 & 9.95 \\
Administration Large & 2.85 & 3.18 & - & 9.05 & - & 0.12 & 4.87 & - & 20.07 \\
Administration Small Old & 5.82 & 4.17 & - & 1.40 & - & 0.12 & 4.70 & - & 16.21 \\
Administration Small New & 5.73 & 2.54 & - & 1.54 & - & 0.14 & 5.22 & - & 15.17 \\
Vehicle Maintenance & 0.49 & 0.57 & - & 0.43 & - & 0.24 & 2.21 & 0.04 & 3.98 \\
Hospital & 6.24 & 1.72 & 0.68 & 11.81 & 0.61 & 0.33 & 9.40 & - & 30.79 \\
Residential & 4.98 & 0.41 & 0.21 & 3.51 & 0.79 & 0.35 & 0.73 & - & 10.98 \\
Warehouse & 1.16 & 0.34 & - & 0.59 & - & 0.32 & 2.20 & - & 4.61 \\
Miscellaneous & 4.64 & 0.84 & 0.06 & 1.91 & 0.22 & 0.29 & 5.99 & - & 13.95 \\
\hline
\end{tabular}




\section{Methodology}

Two approaches were employed to estimate electricity use at Army installations. The first was called 'EDA estimated', which utilized DOE-2 simulations of HVAC electricity use in combination with Fort Hood DOE-2 simulated and EDA reconciled EUIs, and IFS building inventory data to obtain electricity use data by building type and end use. The second was called 'utility estimated', which integrated electrical utility billing data, the Fort Hood EDA temperature-independent to temperature-dependent HVAC electricity use ratio, and non-HVAC EDA estimates from the first approach to determine electricity use by end use for the entire facility. These two approaches are illustrated in Figure 4-1 with EDA estimated shown on the left (1) and utility estimated on the right (2).

\section{EDA Estimated Approach}

The 11 building prototypes identified in Table 1-1 were simulated with the building energy simulation program DOE-2.1D (BESG, 1990) using nearby weather data for each installation to obtain annual simulated HVAC EUIs (cooling, ventilation, and gas heating). The annual simulated HVAC electric end-use EUIs (cooling and ventilation) for each installation and building type were divided by the annual simulated HVAC electric end-use EUIs from Fort Hood of like building type, to obtain simulation scaling ratios as in equation [1], where the subscript ' $i$ ' identifies the installation, ' $j$ ' the building type, and ' $k$ ' the enduse.

DOE2_EUI_RATIO ${ }_{\text {annual,hvac,i,j,k }}=\frac{\text { DOE2_EUI annual,hvac,i,j,k }}{\text { DOE2_EUI annual,hvac,FtHood, }, \mathrm{j}, \mathrm{k}}$

The simulation scaling ratios were then multiplied by the annual EDA reconciled electric HVAC EUIs from Fort Hood for each installation and building type to obtain EDA estimated EUIs as in equation [2]. The EDA non-HVAC end-use EUIs were assumed to be uniform for all installations, and hence were not modified from the Fort Hood EDA reconciled EUIs, equation [3]. EDA reconciled EUIs from Phase I applicable to Phase II are shown in Table 3-4.

EDA_EUI $I_{\text {annual,hvac,i,j,k }}=$ DOE2_EUI_RATIO ${ }_{\text {annual,hvac,i,j,k }} \times$ EDA_EUI $_{\text {annual,hvac,FtHood,j,k }}$

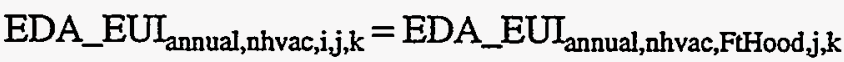

The EDA estimated annual HVAC and non-HVAC electricity use by building type and end use were calculated by multiplying the EDA estimated EUIs by the total building floor area from Table 3-1 as in equation [4].

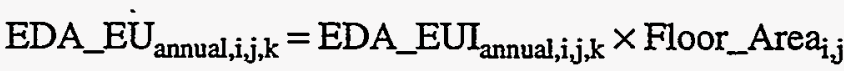




\section{Utility Estimated Approach}

The 1993 monthly utility billing data were separated into three components; temperature-dependent HVAC, temperature-independent HVAC, and non-HVAC, for each installation as shown in Figure 4-2.

Two seasons were observed; winter and summer. The winter season exhibited temperature-independent behavior, therefore a winter average was defined as the mean load during these months. The summer season exhibited both temperature-dependent and temperature-independent behavior. The summer temperature-independent component was defined as equal to the winter average load and the summer temperature-dependent component was defined as the total load less the summer temperature-independent component. The summer temperature-dependent component was attributed completely to HVAC use. The temperature-independent component was divided into HVAC and non-HVAC components. Since the temperature-dependent HVAC component was known, the temperature-independent HVAC component could be found from the ratio of EDA temperature-independent HVAC to temperature-dependent HVAC at Fort Hood. The total HVAC electricity use of the installation was the sum of the temperaturedependent HVAC component and the temperature-independent HVAC component. The non-HVAC component was the total less the HVAC component.

The ratio of the utility non-HVAC component and the sum of EDA estimated non-HVAC end uses for an entire installation was defined as whole-installation non-HVAC electricity use saturation. The 'Utility Estimated' non-HVAC end-use electricity consumption was calculated by scaling the 'EDA Estimated' non-HVAC electricity use by end use of the entire installation by the whole-installation non-HVAC saturation as in equation [5].

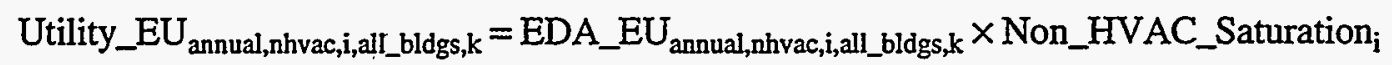


Figure 4-1. Two approaches to estimating electricity use at U.S. Army installations; (1) EDA Estimated and (2) Utility Estimated.

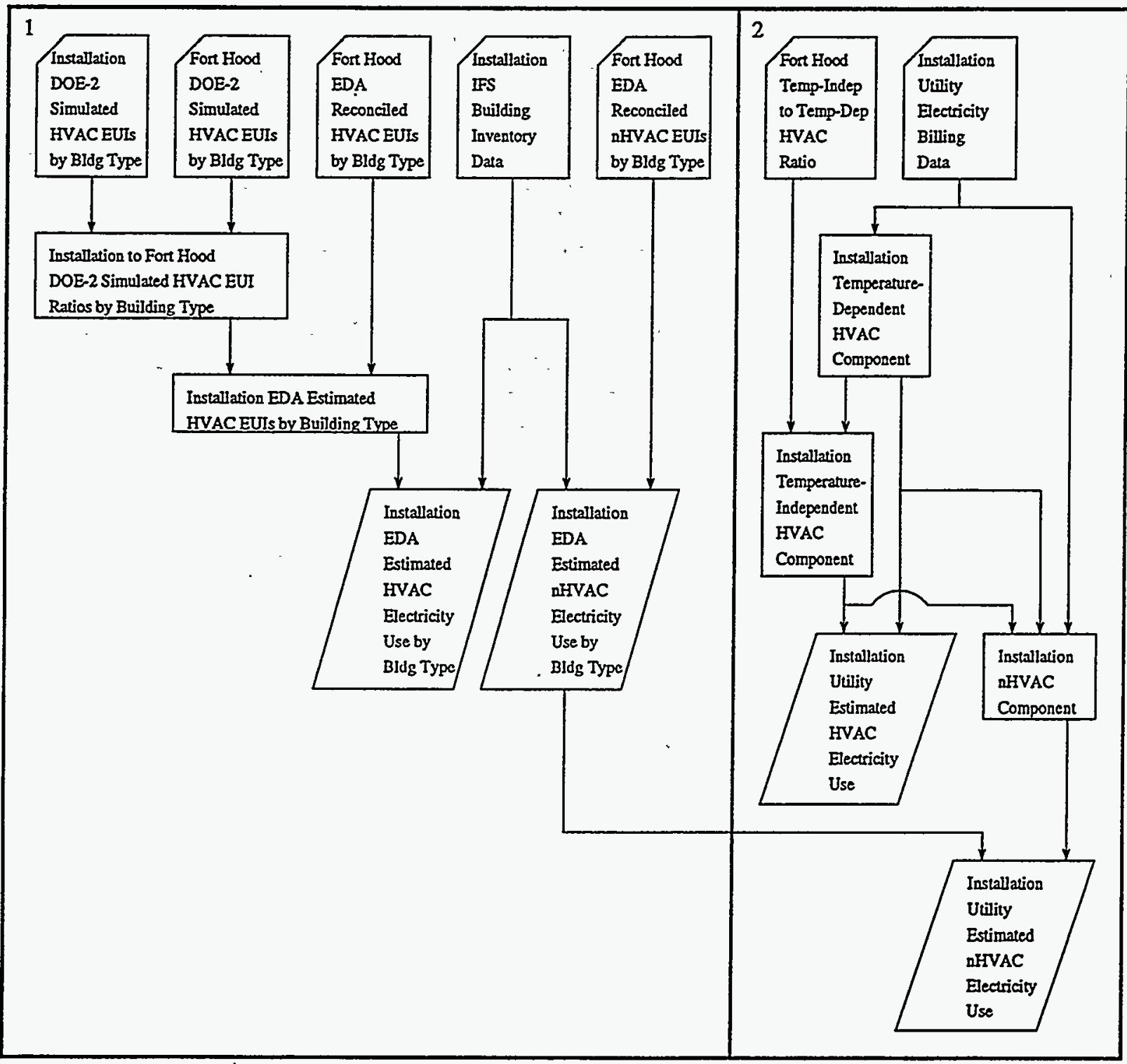


Figure 4-2. Monthly electrical utility billing data for Fort Benning depicting temperature-dependent HVAC, temperature-independent HVAC, and non-HVAC annual components.

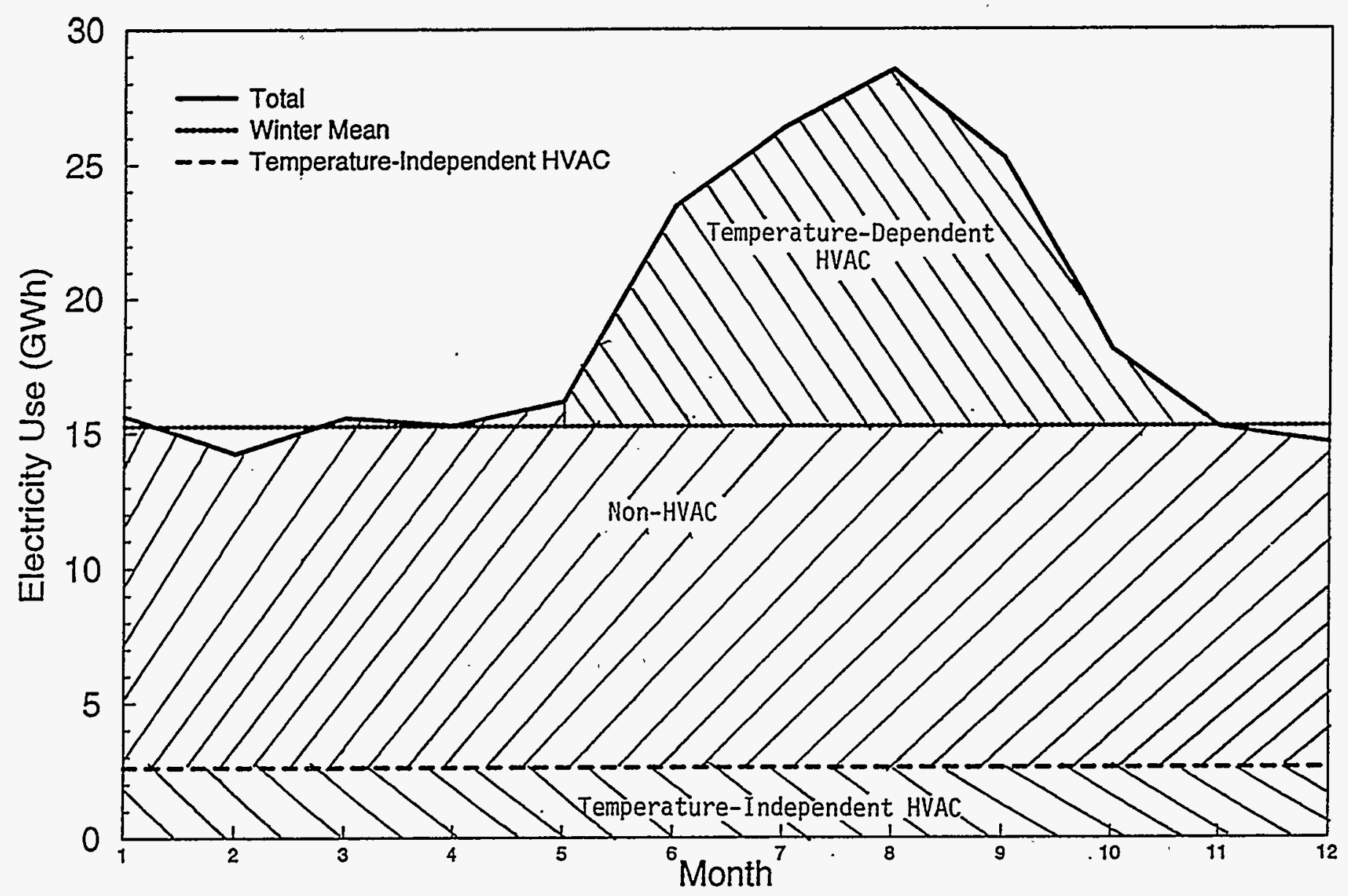




\section{Results}

\section{Annual DOE-2 Simulated and EDA Estimated HVAC EUIs}

Annual HVAC end-use EUIs from DOE-2 simulations and EDA estimates are shown in Tables 5-1 through 5-12. The electric cooling and ventilation end uses are presented for simulations and EDA estimates. The gas heating end use was simulated only, since measured gas use data were not available. The EDA estimates were those derived from equation [2] in section 4.

\section{Annual EDA Estimated Electricity Use}

Annual HVAC and Non-HVAC end-use electricity consumption estimates are shown in Tables 5-13 through 5-24. These estimates were obtained by scaling the EDA estimated end-use EUIs by the floor area of each building type, per equation [4] in section 4 .

\section{Comparison of Utility Billing Data and EDA Estimates}

A comparison of utility billing data divided into HVAC and non-HVAC components with EDA estimated electricity usage divided into HVAC and Non-HVAC end uses is shown in Table 5-25. Additionally, the relative error of the total utility data versus the total EDA estimated electricity use is displayed as is the whole-installation non-HVAC electricity use saturation. The non-HVAC estimates included street lighting and transmission losses, which each accounted for 5\% of the annual utility billing data (Akbari and Konopacki, 1995). The comparison is also displayed in Figure 5-1, where the first column in each pair are utility billing data components and the second column are EDA estimates.

An air-conditioning saturation of $100 \%$ was assumed in all building types for all locations along with location-dependent HVAC schedules. Typically, residences and hospitals are the only buildings with $100 \%$ saturation, some administration type buildings have ventilation only, and many warehouse and vehicle maintenance buildings do not have air-conditioning. It is reasonable to assume that airconditioning saturation was less than $100 \%$, but there were no data to estimate this quantity. A comparison of Utility and EDA HVAC estimates revealed that the EDA estimated HVAC end use was always greater than the utility billing HVAC component, except for Yuma Pg, which was the location of highest cooling-degree-days. This indicated that air-conditioning saturation was less than $100 \%$ for these installations. The HVAC electricity use estimated by EDA was within $1 \%$ of the utility billing HVAC component for Fort Sam Houston, which is located in San Antonio due south a couple hundred miles from Fort Hood, within $15 \%$ for Fort Benning, within $36 \%$ for 4 others, and within $84 \%$ for 4 others.

The EDA estimated non-HVAC end use was less (except for Fort Dix and Fort Sill) than the utility billing non-HVAC component because of the non-representation of industrial process end uses within the EDA estimates, and/or the Fort Hood non-HVAC EUIs were not applicable. The industrial process end uses may account for a substantial portion of electricity consumption, however there were no data available to estimate these. The non-HVAC electricity use estimated by EDA was within 5\% of the utility billing non-HVAC component for three installations, Fort Dix, Fort Benning, and Fort Polk, within 18\% for 5 others, and within $48 \%$ for the rest.

There were 6 installations where the 1993 electricity consumption was estimated to within 11\%, Fort Benning, Fort Polk, Fort Benjamin Harrison, Fort Leonard Wood, Fort Irwin and Fort Sam Houston. There were 4 installations where the 1993 electricity consumption was estimated to within $25 \%$, Fort Belvoir, Fort Bragg, Fort Sill, and Fort Bliss. There was 1 installation where the 1993 electricity consumption was estimated to within 34\%, Fort Dix. 
Table 5-1. Annual DOE-2 Simulated and EDA Estimated HVAC EUIs at Fort Dix

\begin{tabular}{|l||c|c|c||c|c|}
\hline \multirow{2}{*}{ Building } & \multicolumn{3}{c||}{ DOE-2 } & \multicolumn{2}{c|}{ EDA } \\
\cline { 2 - 6 } & $\begin{array}{c}\text { Cooling } \\
\mathrm{kWh} / \mathrm{ft}^{2}\end{array}$ & $\begin{array}{c}\text { Ventilation } \\
\mathrm{kWh} / \mathrm{ft}^{2}\end{array}$ & $\begin{array}{c}\text { Heating } \\
\mathrm{kBtu} / \mathrm{ft}^{2}\end{array}$ & $\begin{array}{c}\text { Cooling } \\
\mathrm{kWh} / \mathrm{ft}^{2}\end{array}$ & $\begin{array}{c}\text { Ventilation } \\
\mathrm{kWh} / \mathrm{ft}^{2}\end{array}$ \\
\hline \hline Barrack & 1.79 & 1.15 & 14.67 & 1.95 & 2.05 \\
Dining Hall & 2.70 & 0.96 & 28.70 & 2.54 & 2.09 \\
Gymnasium & 0.67 & 0.93 & 62.17 & 0.98 & 1.21 \\
Administration Large & 2.34 & 3.67 & 0.80 & 1.55 & 3.08 \\
Administration Small Old & 2.84 & 3.43 & 53.75 & 2.47 & 4.50 \\
Administration Small New & 2.12 & 2.49 & 34.26 & 2.46 & 2.61 \\
Vehicle Maintenance & 0.20 & 0.34 & 83.54 & 0.21 & 0.84 \\
Hospital & 5.64 & 2.77 & 27.42 & 4.33 & 1.68 \\
Residential & 2.55 & 0.23 & 30.51 & 2.22 & 0.21 \\
Warehousé & 0.36 & 0.39 & 35.01 & 0.60 & 0.46 \\
Miscellaneous & 1.83 & 1.36 & 19.77 & 1.89 & 0.96 \\
\hline
\end{tabular}

Table 5-2. Annual DOE-2 Simulated and EDA Estimated HVAC EUIs at Fort Belvoir

\begin{tabular}{|l||c|c|c||c|c|}
\hline \multirow{2}{*||}{ Building } & \multicolumn{3}{c||}{ DOE-2 } & \multicolumn{2}{c|}{ EDA } \\
\cline { 2 - 6 } & $\begin{array}{c}\text { Cooling } \\
\mathrm{kWh} / \mathrm{ft}^{2}\end{array}$ & $\begin{array}{c}\text { Ventilation } \\
\mathrm{kWh} / \mathrm{ft}^{2}\end{array}$ & $\begin{array}{c}\text { Heating } \\
\mathrm{kBtu} / \mathrm{ft}^{2}\end{array}$ & $\begin{array}{c}\text { Cooling } \\
\mathrm{kWh} / \mathrm{ft}^{2}\end{array}$ & $\begin{array}{c}\text { Ventilation } \\
\mathrm{kWh} / \mathrm{ft}^{2}\end{array}$ \\
\hline \hline Barrack & 2.06 & 1.19 & 11.79 & 2.25 & 2.12 \\
Dining Hall & 2.92 & 0.88 & 21.94 & 2.74 & 1.92 \\
Gymnasium & 0.73 & 0.88 & 54.55 & 1.07 & 1.15 \\
Administration Large & 2.62 & 3.76 & 0.62 & 1.74 & 3.15 \\
Administration Small Old & 3.19 & 3.40 & 48.77 & 2.78 & 4.46 \\
Administration Small New & 2.39 & 2.53 & 31.01 & 2.78 & 2.66 \\
Vehicle Maintenance & 0.22 & 0.27 & 68.22 & 0.23 & 0.67 \\
Hospital & 6.34 & 2.79 & 23.63 & 4.87 & 1.70 \\
Residential & 2.61 & 0.24 & 24.72 & 2.28 & 0.22 \\
Warehouse & 0.38 & 0.39 & 29.08 & 0.63 & 0.46 \\
Miscellaneous & 2.10 & 1.44 & 17.18 & 2.17 & 1.02 \\
\hline
\end{tabular}

Table 5-3. Annual DOE-2 Simulated and EDA Estimated HVAC EUIs at Fort Bragg

\begin{tabular}{|l||c|c|r||c|c|}
\hline \multirow{2}{*}{\multicolumn{1}{|c||}{ Building }} & \multicolumn{3}{c||}{ DOE-2 } & \multicolumn{2}{c|}{ EDA } \\
\cline { 2 - 6 } & $\begin{array}{c}\text { Cooling } \\
\mathrm{kWh} / \mathrm{ft}^{2}\end{array}$ & $\begin{array}{c}\text { Ventilation } \\
\mathrm{kWh} / \mathrm{ft}^{2}\end{array}$ & $\begin{array}{c}\text { Heating } \\
\mathrm{kBtu} / \mathrm{ft}^{2}\end{array}$ & $\begin{array}{c}\text { Cooling } \\
\mathrm{kWh} / \mathrm{ft}^{2}\end{array}$ & $\begin{array}{c}\text { Ventilation } \\
\mathrm{kWh} / \mathrm{ft}^{2}\end{array}$ \\
\hline \hline Barrack & 2.59 & 1.14 & 7.38 & 2.83 & 2.03 \\
Dining Hall & 3.89 & 0.88 & 14.02 & 3.65 & 1.92 \\
Gymnasium & 1.02 & 0.83 & 41.26 & 1.49 & 1.08 \\
Administration Large & 2.96 & 3.66 & 0.39 & 1.97 & 3.07 \\
Administration Small OId & 4.37 & 3.23 & 32.88 & 3.81 & 4.24 \\
Administration Small New & 3.25 & 2.38 & 21.17 & 3.78 & 2.50 \\
Vehicle Maintenance & 0.30 & 0.24 & 44.55 & 0.31 & 0.59 \\
Hospital & 6.88 & 2.78 & 18.21 & 5.28 & 1.69 \\
Residential & 3.82 & 0.31 & 17.06 & 3.33 & 0.28 \\
Warehouse & 0.50 & 0.37 & 20.07 & 0.83 & 0.43 \\
Miscellaneous & 2.89 & 1.31 & 11.38 & 2.98 & 0.92 \\
\hline
\end{tabular}


Table 5-4. Annual DOE-2 Simulated and EDA Estimated HVAC EUIs at Fort Benning

\begin{tabular}{|l||r|r|r||r|r|}
\hline \multirow{2}{*}{ Building } & \multicolumn{3}{c||}{ DOE-2 } & \multicolumn{2}{c|}{ EDA } \\
\cline { 2 - 6 } & $\begin{array}{c}\text { Cooling } \\
\mathrm{kWh} / \mathrm{ft}^{2}\end{array}$ & $\begin{array}{c}\text { Ventilation } \\
\mathrm{kWh} / \mathrm{ft}^{2}\end{array}$ & $\begin{array}{r}\text { Heating } \\
\mathrm{kBtu} / \mathrm{ft}^{2}\end{array}$ & $\begin{array}{r}\text { Cooling } \\
\mathrm{kWh} / \mathrm{ft}^{2}\end{array}$ & $\begin{array}{c}\text { Ventilation } \\
\mathrm{kWh} / \mathrm{ft}^{2}\end{array}$ \\
\hline \hline Barrack & 3.05 & 1.14 & 6.43 & 3.33 & 2.03 \\
Dining Hall & 4.79 & 0.88 & 12.58 & 4.50 & 1.92 \\
Gymnasium & 1.07 & 0.83 & 36.78 & 1.56 & 1.08 \\
Administration Large & 3.14 & 3.76 & 0.31 & 2.09 & 3.15 \\
Administration Small Old & 4.59 & 3.27 & 29.32 & 4.00 & -4.29 \\
Administration Small New & 3.41 & 2.41 & 18.82 & 3.96 & 2.53 \\
Vehicle Maintenance & 0.32 & 0.24 & 41.73 & 0.33 & 0.59 \\
Hospital & 7.24 & 2.79 & 15.57 & 5.56 & 1.70 \\
Residential & 3.93 & 0.33 & 14.85 & 3.43 & 0.30 \\
Warehouse & 0.51 & 0.37 & 18.14 & 0.85 & 0.43 \\
Miscellaneous & 3.04 & 1.35 & 9.60 & 3.13 & 0.95 \\
\hline
\end{tabular}

Table 5-5. Annual DOE-2 Simulated and EDA Estimated HVAC EUIs at Fort Polk

\begin{tabular}{|l||r|r|r||r|r|}
\hline \multicolumn{1}{|c||}{ Building } & \multicolumn{3}{c||}{ DOE-2 } & \multicolumn{2}{c|}{ EDA } \\
\cline { 2 - 6 } & $\begin{array}{c}\text { Cooling } \\
\mathrm{kWh} / \mathrm{ft}^{2}\end{array}$ & $\begin{array}{c}\text { Ventilation } \\
\mathrm{kWh} / \mathrm{ft}^{2}\end{array}$ & $\begin{array}{r}\text { Heating } \\
\mathrm{kBtw} / \mathrm{ft}^{2}\end{array}$ & $\begin{array}{c}\text { Cooling } \\
\mathrm{kWh} / \mathrm{ft}^{2}\end{array}$ & $\begin{array}{c}\text { Ventilation } \\
\mathrm{kWh} / \mathrm{ft}^{2}\end{array}$ \\
\hline \hline Barrack & 3.83 & 1.22 & 1.79 & 4.18 & 2.18 \\
Dining Hall & 5.85 & 0.88 & 4.62 & 5.50 & 1.92 \\
Gymnasium & 1.35 & 0.64 & 15.17 & 1.97 & 0.83 \\
Administration Large & 5.11 & 4.04 & 0.22 & 3.39 & 3.39 \\
Administration Small Old & 5.89 & 3.41 & 8.82 & 5.13 & 4.47 \\
Administration Small New & 4.44 & 2.60 & 5.45 & 5.16 & 2.73 \\
Vehicle Maintenance & 0.41 & 0.23 & 16.14 & 0.43 & 0.57 \\
Hospital & 9.42 & 2.82 & 9.64 & 7.23 & 1.71 \\
Residential & 4.92 & 0.38 & 7.50 & 4.29 & 0.35 \\
Warehouse & 0.62 & 0.24 & 6.23 & 1.03 & 0.28 \\
Miscellaneous & 4.09 & 1.39 & 2.44 & 4.22 & 0.98 \\
\hline
\end{tabular}

Table 5-6. Annual DOE-2 Simulated and EDA Estimated HVAC EUIs at Fort Benjamin Harrison

\begin{tabular}{|l||c|c|c||c|c|}
\hline \multicolumn{1}{|c||}{ Building } & \multicolumn{3}{c||}{ DOE-2 } & \multicolumn{2}{c|}{ EDA } \\
\cline { 2 - 6 } & $\begin{array}{c}\text { Cooling } \\
\mathrm{kWh} / \mathrm{ft}^{2}\end{array}$ & $\begin{array}{c}\text { Ventilation } \\
\mathrm{kWh} / \mathrm{ft}^{2}\end{array}$ & $\begin{array}{c}\text { Heating } \\
\mathrm{kBtu} / \mathrm{ft}^{2}\end{array}$ & $\begin{array}{c}\text { Cooling } \\
\mathrm{kWh} / \mathrm{ft}^{2}\end{array}$ & $\begin{array}{c}\text { Ventilation } \\
\mathrm{kWh} / \mathrm{ft}^{2}\end{array}$ \\
\hline \hline Barrack & 1.91 & 1.11 & 19.92 & 2.08 & 1.98 \\
Dining Hall & 2.94 & 0.88 & 36.07 & 2.76 & 1.92 \\
Gymnasium & 0.90 & 1.13 & 75.09 & 1.31 & 1.47 \\
Administration Large & 2.34 & 3.54 & 1.36 & 1.55 & 2.97 \\
Administration Small Old & 3.65 & 3.50 & 73.62 & 3.18 & 4.59 \\
Administration Small New & 2.68 & 2.50 & 47.04 & 3.11 & 2.62 \\
Vehicle Maintenance & 0.25 & 0.35 & 98.52 & 0.26 & 0.87 \\
Hospital & 5.51 & 2.78 & 31.76 & 4.23 & 1.69 \\
Residential & 3.09 & 0.31 & 38.52 & 2.69 & 0.28 \\
Warehouse & 0.45 & 0.48 & 42.31 & 0.75 & 0.56 \\
Miscellaneous & 2.33 & 1.65 & 29.73 & 2.40 & 1.16 \\
\hline
\end{tabular}


Table 5-7. Annual DOE-2 Simulated and EDA Estimated HVAC EUIs at Fort Leonard Wood

\begin{tabular}{|l||c|c|r||r|r|}
\hline \multirow{2}{*}{\multicolumn{1}{|c||}{ Building }} & \multicolumn{3}{c||}{ DOE-2 } & \multicolumn{2}{c|}{ EDA } \\
\cline { 2 - 6 } & $\begin{array}{c}\text { Cooling } \\
\mathrm{kWh} / \mathrm{ft}^{2}\end{array}$ & $\begin{array}{c}\text { Ventilation } \\
\mathrm{kWh} / \mathrm{ft}^{2}\end{array}$ & $\begin{array}{c}\text { Heating } \\
\mathrm{kBtu} / \mathrm{ft}^{2}\end{array}$ & $\begin{array}{r}\text { Cooling } \\
\mathrm{kWh} / \mathrm{ft}^{2}\end{array}$ & $\begin{array}{c}\text { Ventilation } \\
\mathrm{kWh} / \mathrm{ft}^{2}\end{array}$ \\
\hline \hline Barrack & 2.50 & 1.15 & 14.88 & 2.73 & 2.05 \\
Dining Hall & 4.16 & 0.88 & 27.84 & 3.91 & 1.92 \\
Gymnasium & 1.00 & 1.01 & 61.68 & 1.46 & 1.32 \\
Administration Large & 2.61 & 3.73 & 1.08 & 1.73 & 3.13 \\
Administration Small Old & 4.22 & 3.49 & 56.65 & 3.68 & 4.58 \\
Administration Small New & 3.08 & 2.54 & 36.16 & 3.58 & 2.67 \\
Vehicle Maintenance & 0.29 & 0.33 & 77.88 & 0.30 & 0.82 \\
Hospital & 6.44 & 2.81 & 26.68 & 4.94 & 1.71 \\
Residential & 3.63 & 0.33 & 29.39 & 3.17 & 0.30 \\
Warehouse & 0.49 & 0.46 & 32.68 & 0.81 & 0.54 \\
Miscellaneous & 2.71 & 1.50 & 21.27 & 2.79 & 1.06 \\
\hline
\end{tabular}

Table 5-8. Annual DOE-2 Simulated and EDA Estimated HVAC EUIs at Fort Irwin

\begin{tabular}{|l||r|r|r||r|r|}
\hline \multirow{2}{*}{ Building } & \multicolumn{3}{|c||}{ DOE-2 } & \multicolumn{2}{c|}{ EDA } \\
\cline { 2 - 6 } & $\begin{array}{c}\text { Cooling } \\
\mathrm{kWh} / \mathrm{ft}^{2}\end{array}$ & $\begin{array}{c}\text { Ventilation } \\
\mathrm{kWh} / \mathrm{ft}^{2}\end{array}$ & $\begin{array}{c}\text { Heating } \\
\mathrm{kBtu} / \mathrm{ft}^{2}\end{array}$ & $\begin{array}{r}\text { Cooling } \\
\mathrm{kWh} / \mathrm{ft}^{2}\end{array}$ & $\begin{array}{c}\text { Ventilation } \\
\mathrm{kWh} / \mathrm{ft}^{2}\end{array}$ \\
\hline \hline Barrack & 3.14 & 1.46 & 2.25 & 3.43 & 2.61 \\
Dining Hall & 5.93 & 1.23 & 5.23 & 5.57 & 2.68 \\
Gymnasium & 1.42 & 0.74 & 25.32 & 2.07 & 0.97 \\
Administration Large & 3.59 & 4.53 & 0.15 & 2.38 & 3.80 \\
Administration Small Old & 6.41 & 4.10 & 13.99 & 5.58 & 5.38 \\
Administration Small New & 4.67 & 2.97 & 9.67 & 5.43 & 3.12 \\
Vehicle Maintenance & 0.46 & 0.30 & 11.62 & 0.48 & 0.74 \\
Hospital & 8.02 & 2.99 & 9.27 & 6.16 & 1.82 \\
Residential & 7.14 & 0.43 & 7.62 & 6.23 & 0.39 \\
Warehouse & 0.71 & 0.32 & 8.54 & 1.18 & 0.38 \\
Miscellaneous & 4.13 & 1.49 & 4.00 & 4.26 & 1.05 \\
\hline
\end{tabular}

Table 5-9. Annual DOE-2 Simulated and EDA Estimated HVAC EUIs at Fort Sill

\begin{tabular}{|l||c|c|r||r|r|}
\hline \multirow{2}{*}{ Building } & \multicolumn{3}{c||}{ DOE-2 } & \multicolumn{2}{c|}{ EDA } \\
\cline { 2 - 6 } & $\begin{array}{r}\text { Cooling } \\
\mathrm{kWh} / \mathrm{ft}^{2}\end{array}$ & $\begin{array}{c}\text { Ventilation } \\
\mathrm{kWh} / \mathrm{ft}^{2}\end{array}$ & $\begin{array}{c}\text { Heating } \\
\mathrm{kBtu} / \mathrm{ft}^{2}\end{array}$ & $\begin{array}{r}\text { Cooling } \\
\mathrm{kWh} / \mathrm{ft}^{2}\end{array}$ & $\begin{array}{c}\text { Ventilation } \\
\mathrm{kWh} / \mathrm{ft}^{2}\end{array}$ \\
\hline \hline Barrack & 2.75 & 1.24 & 8.67 & 3.00 & 2.21 \\
Dining Hall & 4.48 & 0.96 & 17.92 & 4.21 & 2.09 \\
Gymnasium & 1.29 & 0.86 & 46.73 & 1.88 & 1.12 \\
Administration Large & 3.40 & 3.89 & 0.51 & 2.26 & 3.26 \\
Administration Small Old & 5.45 & 3.51 & 36.43 & 4.75 & 4.60 \\
Administration Small New & 3.99 & 2.57 & 23.75 & 4.64 & 2.70 \\
Vehicle Maintenance & 0.39 & 0.33 & 67.25 & 0.41 & 0.82 \\
Hospital & 7.31 & 2.83 & 19.40 & 5.61 & 1.72 \\
Residential & 4.76 & 0.41 & 19.56 & 4.15 & 0.37 \\
Warehouse & 0.61 & 0.38 & 25.48 & 1.01 & 0.45 \\
Miscellaneous & 3.53 & 1.35 & 12.61 & 3.64 & 0.95 \\
\hline
\end{tabular}


Table 5-10. Annual DOE-2 Simulated and EDA Estimated HVAC EUIs at Yuma Pg

\begin{tabular}{|l||r|r|r||r|r|}
\hline \multirow{2}{*}{\multicolumn{1}{|c||}{ Building }} & \multicolumn{3}{c||}{ DOE-2 } & \multicolumn{2}{c|}{ EDA } \\
\cline { 2 - 6 } & $\begin{array}{r}\text { Cooling } \\
\mathrm{kWh} / \mathrm{ft}^{2}\end{array}$ & $\begin{array}{c}\text { Ventilation } \\
\mathrm{kWh} / \mathrm{ft}^{2}\end{array}$ & $\begin{array}{r}\text { Heating } \\
\mathrm{kBtu} / \mathrm{ft}^{2}\end{array}$ & $\begin{array}{r}\text { Cooling } \\
\mathrm{kWh} / \mathrm{ft}^{2}\end{array}$ & $\begin{array}{c}\text { Ventilation } \\
\mathrm{kWh} / \mathrm{ft}^{2}\end{array}$ \\
\hline \hline Barrack & 3.50 & 1.55 & 0.88 & 3.82 & 2.77 \\
Dining Hall & 6.75 & 1.23 & 4.35 & 6.34 & 2.68 \\
Gymnasium & 1.86 & 0.70 & 11.57 & 2.71 & 0.91 \\
Administration Large & 4.05 & 4.74 & 0.03 & 2.69 & 3.98 \\
Administration Small Old & 7.94 & 4.29 & 4.46 & 6.92 & 5.63 \\
Administration Small New & 5.81 & 3.09 & 3.26 & 6.75 & 3.24 \\
Vehicle Maintenance & 0.59 & 0.32 & 7.96 & 0.62 & 0.79 \\
Hospital & 9.72 & 3.00 & 7.72 & 7.46 & 1.82 \\
Residential & 8.03 & 0.52 & 5.26 & 7.00 & 0.47 \\
Warehouse & 0.87 & 0.29 & 3.72 & 1.44 & 0.34 \\
Miscellaneous & 5.20 & 1.62 & -0.87 & 5.36 & 1.14 \\
\hline
\end{tabular}

Table 5-11. Annual DOE-2 Simulated and EDA Estimated HVAC EUIs at Fort Bliss

\begin{tabular}{|l||r|r|r||r|r|}
\hline \multicolumn{1}{|l||}{ Building } & \multicolumn{3}{c||}{ DOE-2 } & \multicolumn{2}{c|}{ EDA } \\
\cline { 2 - 6 } & $\begin{array}{c}\text { Cooling } \\
\mathrm{kWh} / \mathrm{ft}^{2}\end{array}$ & $\begin{array}{c}\text { Ventilation } \\
\mathrm{kWh} / \mathrm{ft}^{2}\end{array}$ & $\begin{array}{c}\text { Heating } \\
\mathrm{kBtu} / \mathrm{ft}^{2}\end{array}$ & $\begin{array}{r}\text { Cooling } \\
\mathrm{kWh} / \mathrm{ft}^{2}\end{array}$ & $\begin{array}{c}\text { Ventilation } \\
\mathrm{kWh} / \mathrm{ft}^{2}\end{array}$ \\
\hline \hline Barrack & 2.61 & 1.34 & 2.95 & 2.85 & 2.39 \\
Dining Hall & 4.41 & 0.96 & 7.67 & 4.14 & 2.09 \\
Gymnasium & 0.93 & 0.73 & 27.99 & 1.36 & 0.95 \\
Administration Large & 2.99 & 4.43 & 0.14 & 1.99 & 3.72 \\
Administration Small Old & 4.32 & 3.82 & 14.35 & 3.76 & 5.01 \\
Administration Small New & 3.19 & 2.82 & 10.14 & 3.71 & 2.96 \\
Vehicle Maintenance & 0.30 & 0.30 & 25.82 & 0.31 & 0.74 \\
Hospital & 7.55 & 2.91 & 8.31 & 5.79 & 1.77 \\
Residential & 4.37 & 0.29 & 8.47 & 3.81 & 0.26 \\
Warehouse & 0.49 & 0.32 & 11.82 & 0.81 & 0.38 \\
Miscellaneous & 2.81 & 1.56 & 5.39 & 2.90 & 1.10 \\
\hline
\end{tabular}

Table 5-12. Annual DOE-2 Simulated and EDA Estimated HVAC EUIs at Fort Sam Houston

\begin{tabular}{|l||r|r|r||r|r|}
\hline \multirow{2}{*}{ Building } & \multicolumn{3}{|c||}{ DOE-2 } & \multicolumn{2}{c|}{ EDA } \\
\cline { 2 - 6 } & $\begin{array}{r}\text { Cooling } \\
\mathrm{kWh} / \mathrm{ft}^{2}\end{array}$ & $\begin{array}{c}\text { Ventilation } \\
\mathrm{kWh} / \mathrm{ft}^{2}\end{array}$ & $\begin{array}{r}\text { Heating } \\
\mathrm{kBtu} / \mathrm{ft}^{2}\end{array}$ & $\begin{array}{r}\text { Cooling } \\
\mathrm{kWh} / \mathrm{ft}^{2}\end{array}$ & $\begin{array}{c}\text { Ventilation } \\
\mathrm{kWh} / \mathrm{ft}^{2}\end{array}$ \\
\hline \hline Barrack & 3.45 & 1.26 & 1.86 & 3.76 & 2.25 \\
Dining Hall & 5.68 & 0.96 & 5.07 & 5.34 & 2.09 \\
Gymnasium & 1.55 & 0.70 & 17.60 & 2.26 & 0.91 \\
Administration Large & 4.09 & 4.10 & 0.09 & 2.72 & 3.44 \\
Administration Small Old & 6.65 & 3.47 & 10.53 & 5.79 & 4.55 \\
Administration Small New & 4.94 & 2.61 & 6.47 & 5.74 & 2.74 \\
Vehicle Maintenance & 0.47 & 0.24 & 16.48 & 0.49 & 0.59 \\
Hospital & 9.11 & 2.86 & 9.12 & 6.99 & 1.74 \\
Residential & 5.87 & 0.45 & -7.68 & 5.12 & 0.41 \\
Warehouse & 0.69 & 0.31 & 6.60 & 1.14 & 0.36 \\
Miscellaneous & 4.53 & 1.35 & 2.45 & 4.67 & 0.95 \\
\hline
\end{tabular}


Table 5-13. Annual EDA Estimated Electricity Use at Fort Dix [GWh/yr]

\begin{tabular}{|l||c|c|c|c|c|c|c|r||r|}
\hline Building & Cool & Vent & Cook & Misc & Ref & Ex Lit & In Lit & Prcss & Total \\
\hline \hline Barrack & 3.82 & 4.02 & 0.59 & 3.04 & 4.02 & 0.31 & 3.41 & - & 19.21 \\
Dining Hall & 0.46 & 0.38 & 1.07 & - & 0.83 & 0.02 & 0.67 & - & 3.43 \\
Gymnasium & 0.04 & 0.05 & - & 0.02 & - & 0.01 & 0.22 & 0.00 & 0.33 \\
Administration Large & 0.50 & 0.99 & - & 2.90 & - & 0.04 & 1.56 & - & 5.98 \\
Administration Small Old & 2.04 & 3.71 & - & 1.15 & - & 0.10 & 3.88 & - & 10.88 \\
Administration Small New & 0.29 & 0.31 & - & 0.18 & - & 0.02 & 0.62 & - & 1.42 \\
Vehicle Maintenance & 0.06 & 0.25 & - & 0.13 & - & 0.07 & 0.66 & 0.01 & 1.19 \\
Hospital & 1.85 & 0.72 & 0.29 & 5.04 & 0.26 & 0.14 & 4.02 & - & 12.32 \\
Residential & 4.18 & 0.40 & 0.40 & 6.61 & 1.49 & 0.66 & 1.37 & - & 15.10 \\
Warehouse & 0.36 & 0.28 & - & 0.36 & - & 0.19 & 1.33 & - & 2.52 \\
Miscellaneous & 0.81 & 0.41 & 0.03 & 0.82 & 0.09 & 0.12 & 2.58 & - & 4.87 \\
\hline \hline Total & 14.41 & 11.51 & 2.38 & 20.25 & 6.69 & 1.68 & 20.32 & 0.01 & 77.25 \\
\hline
\end{tabular}

Table 5-14. Annual EDA Estimated Electricity Use at Fort Belvoir [GWh/yr]

\begin{tabular}{|l||c|c|c|c|c|c|c|c||r|}
\hline Building & Cool & Vent & Cook & \multicolumn{1}{c|}{ Misc } & Ref & Ex Lit & In Lit & Prcss & Total \\
\hline \hline Barrack & 1.42 & 1.33 & 0.19 & 0.98 & 1.29 & 0.10 & 1.10 & - & 6.41 \\
Dining Hall & 0.33 & 0.23 & 0.71 & - & 0.55 & 0.02 & 0.44 & - & 2.28 \\
Gymnasium & 0.07 & 0.08 & - & 0.04 & - & 0.01 & 0.40 & 0.01 & 0.61 \\
Administration Large & 2.76 & 4.99 & - & 14.33 & - & 0.19 & 7.71 & - & 29.97 \\
Administration Small Old & 3.22 & 5.16 & - & 1.62 & - & 0.14 & 5.44 & - & 15.58 \\
Administration Small New & 0.23 & 0.22 & - & 0.13 & - & 0.01 & 0.43 & - & 1.02 \\
Vehicle Maintenance & 0.24 & 0.70 & - & 0.45 & - & 0.25 & 2.32 & 0.04 & 4.00 \\
Hospital & 1.27 & 0.44 & 0.18 & 3.07 & .0 .16 & 0.09 & 2.45 & - & 7.66 \\
Residential & 6.95 & 0.67 & 0.64 & 10.70 & 2.41 & 1.07 & 2.22 & - & 24.66 \\
Warehouse & 0.57 & 0.42 & - & 0.54 & - & 0.29 & 2.00 & - & 3.82 \\
Miscellaneous & 1.13 & 0.53 & 0.03 & 0.99 & 0.11 & 0.15 & 3.11 & - & 6.05 \\
\hline \hline Total & 18.18 & 14.78 & 1.75 & 32.85 & 4.52 & 2.32 & 27.62 & 0.05 & 102.06 \\
\hline
\end{tabular}

Table 5-15. Annual EDA Estimated Electricity Use at Fort Bragg [GWh/yr]

\begin{tabular}{|l||r|r|r|r|r|r|r|r||r|}
\hline Building & \multicolumn{1}{|c|}{ Cool } & \multicolumn{1}{|c|}{ Vent } & Cook & \multicolumn{1}{c|}{ Misc } & Ref & Ex Lit & In Lit & Prcss & Total \\
\hline \hline Barrack & 13.31 & 9.55 & 1.41 & 7.29 & 9.64 & 0.75 & 8.18 & - & 50.13 \\
Dining Hall & 1.78 & 0.94 & 2.90 & - & 2.24 & 0.06 & 1.80 & - & 9.72 \\
Gymnasium & 0.32 & 0.24 & - & 0.13 & - & 0.04 & 1.27 & 0.02 & 2.02 \\
Administration Large & 2.69 & 4.19 & - & 12.34 & - & 0.16 & 6.64 & - & 26.01 \\
Administration Small Old & 13.37 & 14.88 & - & 4.91 & - & 0.42 & 16.50 & - & 50.08 \\
Administration Small New & 4.60 & 3.04 & - & 1.87 & - & 0.17 & 6.35 & - & 16.03 \\
Vehicle Maintenance & 0.81 & 1.54 & - & 1.12 & - & 0.63 & 5.78 & 0.10 & 9.98 \\
Hospital & 2.18 & 0.70 & 0.28 & 4.88 & 0.25 & 0.14 & 3.88 & - & 12.31 \\
Residential & 24.60 & 2.07 & 1.55 & 25.93 & 5.84 & 2.59 & 5.39 & - & 67.97 \\
Warehouse & 1.54 & 0.80 & - & 1.09 & - & 0.59 & 4.08 & - & 8.10 \\
Miscellaneous & 2.81 & 0.87 & 0.06 & 1.80 & 0.21 & 0.27 & 5.65 & - & 11.67 \\
\hline \hline Total & 68.01 & 38.80 & 6.20 & 61.36 & 18.18 & 5.82 & 65.52 & 0.12 & 264.01 \\
\hline
\end{tabular}


Table 5-16. Annual EDA Estimated Electricity Use at Fort Benning [GWh/yr]

\begin{tabular}{|l||r|r|r|r|r|r|r|r||r|}
\hline Building & Cool & \multicolumn{1}{|c|}{ Vent } & Cook & \multicolumn{1}{c|}{ Misc } & \multicolumn{1}{c|}{ Ref } & Ex Lit & In Lit & Prcss & Total \\
\hline \hline Barrack & 16.52 & 10.07 & 1.49 & 7.69 & 10.17 & 0.79 & 8.63 & - & 55.36 \\
Dining Hall & 2.08 & 0.89 & 2.75 & - & 2.13 & 0.06 & 1.71 & - & 9.62 \\
Gymnasium & 0.09 & 0.07 & - & 0.04 & - & 0.01 & 0.35 & 0.01 & 0.57 \\
Administration Large & 2.95 & 4.44 & - & 12.76 & - & 0.17 & 6.86 & - & 27.18 \\
Administration Small Old & 7.51 & 8.05 & - & 2.63 & - & -0.23 & 8.82 & - & 27.24 \\
Administration Small New & 1.57 & 1.00 & - & 0.61 & - & 0.06 & 2.07 & - & 5.32 \\
Vehicle Maintenance & 0.40 & 0.72 & - & 0.53 & - & 0.29 & 2.71 & 0.05 & 4.71 \\
Hospital & 2.19 & 0.67 & 0.27 & 4.64 & 0.24 & 0.13 & 3.69 & - & 11.82 \\
Residential & 20.71 & 1.81 & 1.27 & 21.20 & 4.77 & 2.11 & 4.41 & - & 56.28 \\
Warehouse & 0.82 & 0.42 & - & 0.57 & - & 0.31 & 2.13 & - & 4.25 \\
Miscellaneous & 2.49 & 0.76 & 0.05 & 1.52 & 0.18 & 0.23 & 4.77 & - & 10.00 \\
\hline \hline Total & 57.33 & 28.89 & 5.83 & 52.19 & 17.49 & 4.39 & 46.15 & 0.06 & 212.34 \\
\hline
\end{tabular}

Table 5-17. Annual EDA Estimated Electricity Use at Fort Polk [GWh/yr]

\begin{tabular}{|l||r|r|r|r|c|c|c|c||r|}
\hline Building & Cool & Vent & Cook & Misc & Ref & Ex Lit & In Lit & Prcss & Total \\
\hline \hline Barrack & 10.09 & 5.26 & 0.72 & 3.74 & 4.95 & 0.39 & 4.20 & - & 29.35 \\
Dining Hall & 1.25 & 0.43 & 1.35 & - & 1.04 & 0.03 & 0.84 & - & 4.94 \\
Gymnasium & 0.10 & 0.04 & - & 0.03 & - & 0.01 & 0.29 & 0.00 & 0.47 \\
Administration Large & 0.24 & 0.24 & - & 0.64 & - & 0.01 & 0.34 & - & 1.47 \\
Administration Small Old & 5.87 & 5.11 & - & 1.60 & - & 0.14 & 5.38 & - & 18.10 \\
Administration Small New & 5.05 & 2.67 & - & 1.51 & - & 0.14 & 5.11 & - & 14.48 \\
Vehicle Maintenance & 0.54 & 0.72 & - & 0.54 & - & 0.30 & 2.79 & 0.05 & 4.94 \\
Hospital & 2.65 & 0.63 & 0.25 & 4.34 & 0.22 & 0.12 & 3.45 & - & 11.66 \\
Residential & 36.50 & 2.98 & 1.79 & 29.86 & 6.72 & 2.98 & 6.21 & - & 87.04 \\
Warehouse & 0.97 & 0.26 & - & 0.55 & - & 0.30 & 2.06 & - & 4.14 \\
Miscellaneous & 2.47 & 0.57 & 0.04 & 1.12 & 0.13 & 0.17 & 3.50 & - & 8.00 \\
\hline \hline Total & 65.72 & 18.92 & 4.15 & 43.93 & 13.06 & 4.59 & 34.17 & 0.05 & 184.59 \\
\hline
\end{tabular}

Table 5-18. Annual EDA Estimated Electricity Use at Fort Benjamin Harrison [GWh/yr]

\begin{tabular}{|l||c|c|c|c|c|c|c|c||r|}
\hline Building & Cool & Vent & Cook & Misc & Ref & Ex Lit & In Lit & Prcss & Total \\
\hline \hline Barrack & 1.83 & 1.74 & 0.26 & 1.37 & 1.81 & 0.14 & 1.53 & - & 8.69 \\
Dining Hall & 0.15 & 0.10 & 0.32 & - & 0.25 & 0.01 & 0.20 & - & 1.03 \\
Gymnasium & 0.06 & 0.07 & - & 0.03 & - & 0.01 & 0.29 & 0.00 & 0.47 \\
Administration Large & 2.92 & 5.59 & - & 17.03 & - & 0.23 & 9.17 & - & 34.94 \\
Administration Small Old & 0.98 & 1.41 & - & 0.43 & - & 0.04 & 1.45 & - & 4.31 \\
Administration Small New & 0.09 & 0.08 & - & 0.05 & - & 0.00 & 0.15 & - & 0.37 \\
Vehicle Maintenance & 0.02 & 0.07 & - & 0.03 & - & 0.02 & 0.17 & 0.00 & 0.31 \\
Hospital & 0.44 & 0.18 & 0.07 & 1.24 & 0.06 & 0.03 & 0.99 & - & 3.01 \\
Residential & 1.59 & 0.17 & 0.12 & 2.08 & 0.47 & 0.21 & 0.43 & - & 5.07 \\
Warehouse & 0.22 & 0.17 & - & 0.18 & - & 0.10 & 0.66 & - & 1.33 \\
Miscellaneous & 0.66 & 0.32 & 0.02 & 0.53 & 0.06 & 0.08 & 1.66 & - & 3.34 \\
\hline \hline Total & 8.98 & 9.90 & 0.79 & 22.97 & 2.65 & 0.87 & 16.70 & 0.00 & 62.86 \\
\hline
\end{tabular}


Table 5-19. Annual EDA Estimated Electricity Use at Fort Leonard Wood [GWh/yr]

\begin{tabular}{|l||r|r|r|r|c|c|c|c||r|}
\hline Building & Cool & Vent & Cook & \multicolumn{1}{c|}{ Misc } & Ref & Ex Lit & In Lit & Prcss & Total \\
\hline \hline Barrack & 6.57 & 4.93 & 0.72 & 3.73 & 4.93 & 0.38 & 4.18 & - & 25.44 \\
Dining Hall & 1.33 & 0.65 & 2.01 & - & 1.56 & 0.04 & 1.25 & - & 6.84 \\
Gymnasium & 0.15 & 0.13 & - & 0.06 & - & 0.02 & 0.59 & 0.01 & 0.96 \\
Administration Large & 0.94 & 1.70 & - & 4.93 & - & 0.07 & 2.65 & - & 10.30 \\
Administration Small Old & 4.18 & 5.20 & - & 1.59 & - & 0.14 & 5.34 & - & 16.45 \\
Administration Small New & 1.62 & 1.21 & - & 0.70 & - & 0.06 & 2.36 & - & 5.95 \\
Vehicle Maintenance & 0.17 & 0.45 & - & 0.24 & - & 0.13 & 1.22 & 0.02 & 2.23 \\
Hospital & 2.00 & 0.69 & 0.27 & 4.77 & 0.25 & 0.13 & 3.80 & - & 11.91 \\
Residential & 11.27 & 1.07 & 0.75 & 12.48 & 2.81 & 1.24 & 2.60 & - & 32.22 \\
Warehouse & 0.49 & 0.33 & - & 0.36 & - & 0.19 & 1.33 & - & 2.69 \\
Miscellaneous & 1.90 & 0.72 & 0.04 & 1.30 & 0.15 & 0.20 & 4.07 & - & 8.38 \\
\hline \hline Total & 30.60 & 17.09 & 3.79 & 30.16 & 9.70 & 2.60 & 29.39 & 0.03 & 123.35 \\
\hline
\end{tabular}

Table 5-20. Annual EDA Estimated Electricity Use at Fort Irwin [GWh/yr]

\begin{tabular}{|l||c|c|c|c|c|c|c|c||c|}
\hline Building & Cool & Vent & Cook & Misc & Ref & Ex Lit & In Lit & Prcss & Total \\
\hline \hline Barrack & 2.51 & 1.91 & 0.22 & 1.13 & 1.50 & 0.12 & 1.27 & - & 8.66 \\
Dining Hall & 0.53 & 0.26 & 0.57 & - & 0.44 & 0.01 & 0.35 & - & 2.16 \\
Gymnasium & 0.05 & 0.02 & - & 0.01 & - & 0.00 & 0.14 & 0.00 & 0.22 \\
Administration Large & - & - & - & - & - & - & - & - & - \\
Administration Small Old & 1.37 & 1.32 & - & 0.34 & - & 0.03 & 1.15 & - & 4.21 \\
Administration Small New & 3.30 & 1.89 & - & 0.93 & - & 0.08 & 3.17 & - & 9.37 \\
Vehicle Maintenance & 0.24 & 0.37 & - & 0.22 & - & 0.12 & 1.11 & 0.02 & 2.08 \\
Hospital & 0.39 & 0.12 & 0.04 & 0.75 & 0.04 & 0.02 & 0.60 & - & 1.96 \\
Residential & 19.83 & 1.24 & 0.67 & 11.17 & 2.51 & 1.11 & 2.32 & - & 38.85 \\
Warehouse & 0.49 & 0.16 & - & 0.24 & - & 0.13 & 0.91 & - & 1.92 \\
Miscellaneous & 1.22 & 0.30 & 0.02 & 0.55 & 0.06 & 0.08 & 1.71 & - & 3.94 \\
\hline \hline Total & 29.93 & 7.59 & 1.52 & 15.34 & 4.55 & 1.70 & 12.73 & 0.02 & 73.38 \\
\hline
\end{tabular}

Table 5-21. Annual EDA Estimated Electricity Use at Fort Sill [GWh/yr]

\begin{tabular}{|l||r|r|r|r|r|r|r|r||r|}
\hline Building & \multicolumn{1}{|c|}{ Cool } & Vent & Cook & Misc & Ref & Ex Lit & In Lit & Prcss & Total \\
\hline \hline Barrack & 9.83 & 7.24 & 0.98 & 5.08 & 6.72 & 0.52 & 5.70 & - & 36.07 \\
Dining Hall & 1.63 & 0.81 & 2.30 & - & 1.78 & 0.05 & 1.43 & - & 8.00 \\
Gymnasium & 0.12 & 0.07 & - & 0.04 & - & 0.01 & 0.37 & 0.01 & 0.62 \\
Administration Large & 3.47 & 5.00 & - & 13.89 & - & 0.18 & 7.48 & - & 30.02 \\
Administration Small Old & 10.07 & 9.75 & - & 2.97 & - & 0.25 & 9.96 & - & 33.00 \\
Administration Small New & 2.73 & 1.59 & - & 0.91 & - & 0.08 & 3.07 & - & 8.38 \\
Vehicle Maintenance & 0.44 & 0.88 & - & 0.46 & - & 0.26 & 2.37 & 0.04 & 4.45 \\
Hospital & 2.80 & 0.86 & 0.34 & 5.88 & 0.30 & 0.16 & 4.68 & - & 15.01 \\
Residential & 9.78 & 0.87 & 0.49 & 8.27 & 1.86 & 0.82 & 1.72 & - & 23.81 \\
Warehouse & 1.11 & 0.50 & - & 0.65 & - & 0.35 & 2.43 & - & 5.04 \\
Miscellaneous & 2.83 & 0.74 & 0.05 & 1.49 & 0.17 & 0.23 & 4.66 & - & 10.17 \\
\hline \hline Total & 44.80 & 28.31 & 4.16 & 39.64 & 10.83 & 2.91 & 43.87 & 0.05 & 174.56 \\
\hline
\end{tabular}


Table 5-22. Annual EDA Estimated Electricity Use at Yuma Pg [GWh/yr]

\begin{tabular}{|l||c|c|c|c|c|c|c|c||c|}
\hline Building & Cool & Vent & Cook & Misc & Ref & Ex Lit & In Lit & Prcss & Total \\
\hline \hline Barrack & 0.45 & 0.33 & 0.04 & 0.18 & 0.24 & 0.02 & 0.21 & - & 1.47 \\
Dining Hall & 0.08 & 0.03 & 0.08 & - & 0.06 & 0.00 & 0.05 & - & 0.31 \\
Gymnasium & 0.03 & 0.01 & - & 0.01 & - & 0.00 & 0.07 & 0.00 & 0.12 \\
Administration Large & - & - & - & - & - & - & - & - & - \\
Administration Small Old & 1.41 & 1.15 & - & 0.29 & - & 0.02 & 0.96 & - & 3.83 \\
Administration Small New & 0.34 & 0.16 & - & 0.08 & - & 0.01 & 0.26 & - & 0.85 \\
Vehicle Maintenance & 0.06 & 0.08 & - & 0.04 & - & 0.02 & 0.21 & 0.00 & 0.41 \\
Hospital & - & - & - & - & - & - & - & - & - \\
Residential & 3.05 & 0.20 & 0.09 & 1.53 & 0.34 & 0.15 & 0.32 & - & 5.68 \\
Warehouse & 0.24 & 0.06 & - & 0.10 & - & 0.05 & 0.36 & - & 0.80 \\
Miscellaneous & 0.68 & 0.14 & 0.01 & 0.24 & 0.03 & 0.04 & 0.76 & - & 1.90 \\
\hline \hline Total & 6.34 & 2.16 & 0.22 & 2.47 & 0.67 & 0.31 & 3.20 & 0.00 & 15.37 \\
\hline
\end{tabular}

Table 5-23. Annual EDA Estimated Electricity Use at Fort Bliss [GWh/yr]

\begin{tabular}{|l||r|r|r|r|r|r|r|r||r|}
\hline Building & Cool & \multicolumn{1}{|c|}{ Vent } & Cook & \multicolumn{1}{c|}{ Misc } & Ref & Ex Lit & In Lit & Prcss & Total \\
\hline \hline Barrack & 8.14 & 6.83 & 0.86 & 4.43 & 5.86 & 0.46 & 4.97 & - & 31.55 \\
Dining Hall & 1.12 & 0.57 & 1.61 & - & 1.25 & 0.04 & 1.00 & - & 5.59 \\
Gymnasium & 0.21 & 0.15 & - & 0.09 & - & 0.03 & 0.90 & 0.01 & 1.39 \\
Administration Large & 2.01 & 3.76 & - & 9.14 & - & 0.12 & 4.92 & - & 19.95 \\
Administration Small Old & 9.97 & 13.28 & - & 3.71 & - & 0.32 & 12.46 & - & 39.74 \\
Administration Small New & 0.99 & 0.79 & - & 0.41 & - & 0.04 & 1.39 & - & 3.62 \\
Vehicle Maintenance & 0.38 & 0.91 & - & 0.53 & - & 0.30 & 2.72 & 0.05 & 4.89 \\
Hospital & 3.91 & 1.19 & 0.46 & 7.97 & 0.41 & 0.22 & 6.34 & - & 20.50 \\
Residential & 16.61 & 1.13 & 0.92 & 15.30 & 3.44 & 1.53 & 3.18 & - & 42.11 \\
Warehouse & 0.83 & 0.39 & - & 0.61 & - & 0.33 & 2.26 & - & 4.42 \\
Miscellaneous & 2.48 & 0.94 & 0.05 & 1.63 & 0.19 & 0.25 & 5.12 & - & 10.66 \\
\hline \hline Total & 46.65 & 29.94 & 3.90 & 43.82 & 11.15 & 3.64 & 45.26 & 0.06 & 184.41 \\
\hline
\end{tabular}

Table 5-24. Annual EDA Estimated Electricity Use at Fort Sam Houston [GWh/yr]

\begin{tabular}{|l||c|c|c|c|c|c|c|c||r|}
\hline Building & Cöol & Vent & Cook & Misc & Ref & Ex Lit & In Lit & Prcss & Total \\
\hline \hline Barrack & 6.49 & 3.88 & 0.52 & 2.68 & 3.54 & $\overline{0.28}$ & 3.00 & - & 20.40 \\
Dining Hall & 1.01 & 0.39 & 1.12 & - & 0.87 & 0.02 & 0.70 & - & 4.11 \\
Gymnasium & 0.21 & 0.08 & - & 0.06 & - & 0.02 & 0.54 & 0.01 & 0.92 \\
Administration Large & 2.99 & 3.79 & - & 9.96 & - & 0.13 & 5.36 & - & 22.23 \\
Administration Small Old & 7.40 & 5.82 & - & 1.79 & - & 0.15 & 6.01 & - & 21.17 \\
Administration Small New & 0.75 & 0.36 & - & 0.20 & - & 0.02 & 0.69 & - & 2.02 \\
Vehicle Maintenance & 0.15 & 0.19 & - & 0.14 & - & 0.08 & 0.70 & 0.01 & 1.27 \\
Hospital & 4.45 & 1.11 & 0.43 & 7.52 & 0.39 & 0.21 & 5.98 & - & 20.09 \\
Residential & 8.94 & 0.72 & 0.37 & 6.13 & 1.38 & 0.61 & 1.27 & - & 19.41 \\
Warehouse & 1.23 & 0.39 & - & 0.64 & - & 0.35 & 2.38 & - & 4.99 \\
Miscellaneous & 3.00 & 0.61 & 0.04 & 1.23 & 0.14 & 0.19 & 3.85 & - & 9.07 \\
\hline \hline Total & 36.64 & 17.34 & 2.48 & 30.35 & 6.32 & 2.06 & 30.48 & 0.02 & 125.68 \\
\hline
\end{tabular}


Table 5-25. 1993 Electricity Use at U.S. Army Installations from Utility Billing Data and EDA Estimates

\begin{tabular}{|c|c|c|c|c|c|c|c|c|c|c|}
\hline \multirow[b]{2}{*}{ Installation } & \multicolumn{3}{|c|}{ Utility Billing Data (U) } & \multicolumn{3}{|c|}{ EDA Estimate } & \multicolumn{3}{|c|}{$(\mathrm{U}-\mathrm{EDA}) / \mathrm{U} * 100$} & \multirow{2}{*}{$\begin{array}{c}\mathrm{U} / \mathrm{EDA} \dagger \\
\text { Non-HVAC }\end{array}$} \\
\hline & $\begin{array}{l}\text { HVAC } \\
\text { (GWh) }\end{array}$ & $\begin{array}{c}\text { Non-HVAC } \\
\text { (GWh) }\end{array}$ & $\begin{array}{c}\text { Total } \\
\text { (GWh) }\end{array}$ & $\begin{array}{l}\text { HVAC } \\
\text { (GWh) }\end{array}$ & $\begin{array}{c}\text { Non-HVAC } \\
\text { (GWh) }\end{array}$ & $\begin{array}{l}\text { Total } \\
\text { (GWh) }\end{array}$ & $\begin{array}{c}\text { HVAC } \\
(\%)\end{array}$ & $\begin{array}{c}\text { Non-HVAC } \\
(\%)\end{array}$ & $\begin{array}{c}\text { Total } \\
(\%)\end{array}$ & \\
\hline Fort Dix & 7.6 & 54.9 & 62.5 & 25.9 & 57.6 & 83.5 & -240 & -5 & -34 & 0.95 \\
\hline Fort Belvoir & 18.0 & 129.3 & 147.3 & 33.0 & 83.9 & 116.9 & -83 & 35 & 21 & 1.59 \\
\hline Fort Bragg & 66.4 & 315.0 & 381.4 & 106.8 & 195.3 & 302.1 & -61 & 38 & 21 & 1.68 \\
\hline Fort Benning & 74.7 & 153.9 & 228.6 & 86.2 & 149.0 & 235.2 & -15 & 3 & -3 & 1.04 \\
\hline Fort Polk & 65.6 & 124.9 & 190.5 & 84.6 & 119.0 & 203.6 & -29 & 5 & -7 & 1.05 \\
\hline Fort Benjamin Harrison & 14.2 & 57.8 & 72.0 & 18.9 & 51.2 & 70.1 & -33 & 11 & 3 & 1.14 \\
\hline Fort Leonard Wood & 30.4 & 105.9 & 136.3 & 47.7 & 89.3 & 137.0 & -57 & 16 & -1 & 1.20 \\
\hline Fort Irwin & 20.4 & 52.4 & 72.8 & 37.5 & 43.1 & 80.6 & -84 & 18 & -11 & 1.24 \\
\hline Fort Sill & 54.7 & 106.2 & 160.9 & 73.1 & 117.5 & 190.6 & -34 & -11 & -18 & 0.90 \\
\hline Yuma Pg & 13.3 & 19.6 & 32.9 & 8.5 & 10.2 & 18.7 & 36 & 48 & 43 & 2.10 \\
\hline Fort Bliss & 24.9 & 135.3 & 160.2 & 76.6 & 123.9 & 200.5 & -207 & 8 & -25 & 1.10 \\
\hline Fort Sam Houston & 53.5 & 99.6 & 153.1 & 54.0 & 87.0 & 141.0 & -1 & 13 & 8 & 1.16 \\
\hline
\end{tabular}

† Whole-installation non-HVAC electricity use saturation 
Figure 5-1. 1993 Electricity Use at U.S. Army Installations by Utility Billing Data and EDA Estimates (first column are utility billing data estimates and second column are EDA estimates).

\section{Electricity Use at U.S. Army Bases Utility Billing Data \& EDA Estimated}

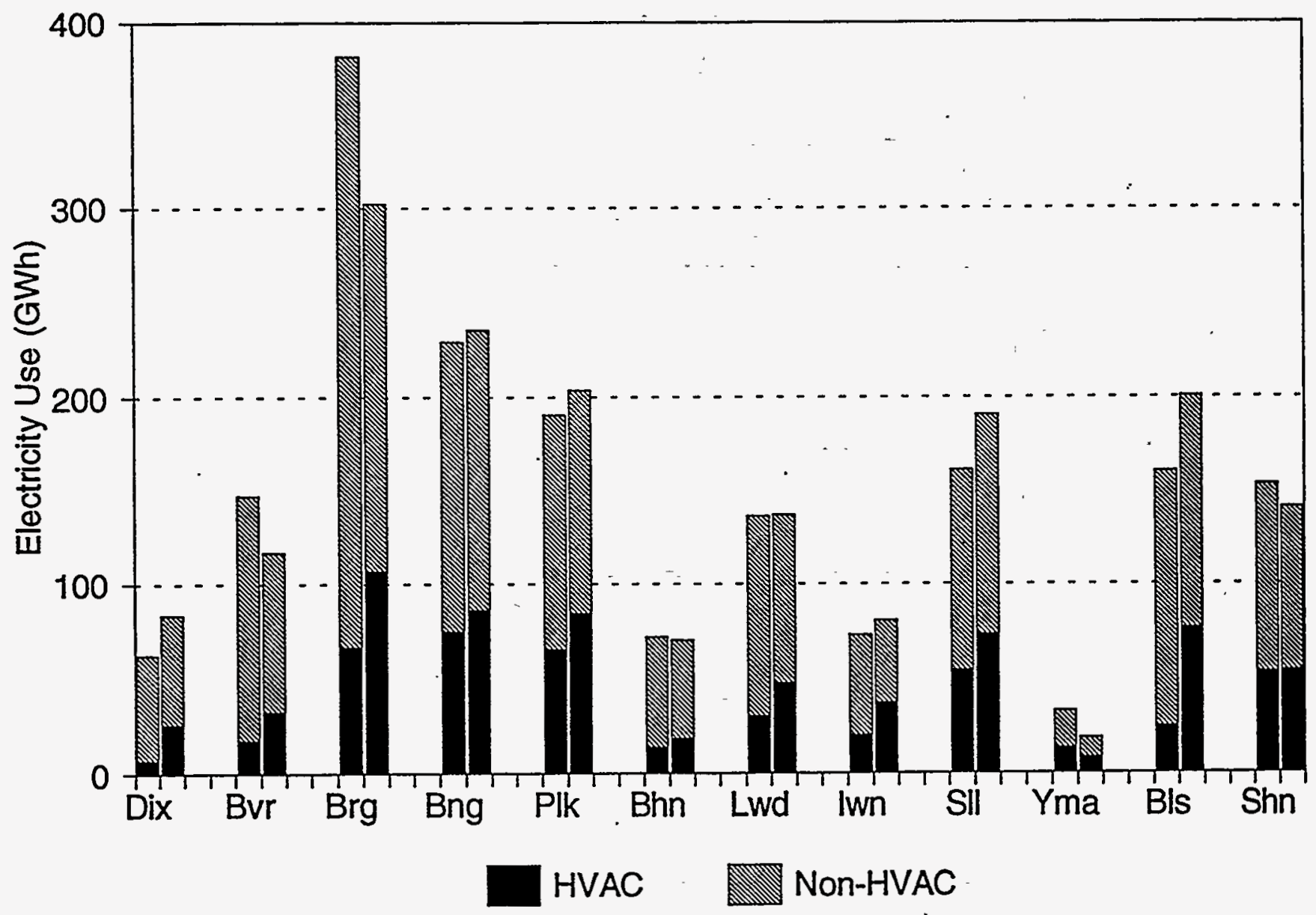




\section{Utility Billing Data Estimated HVAC and Non-HVAC Electricity Use}

The utility billing HVAC estimates shown in Table 5-25 were the sum of temperature-dependent and temperature-independent HVAC components from utility billing data analyses. The utility billing nonHVAC estimates were derived by scaling the annual EDA estimated non-HVAC end uses on an installation level by the whole-installation non-HVAC electricity use saturation, as in equation [5] of section 4. This operation distributed the non-HVAC utility billing component proportionally to the EDA estimated non-HVAC end uses.

Electricity use estimates by end use have been summed for all building types for an entire installation and are presented in Table 5-26 and Figures 5-2 through 5-7. Fort Hood estimates are included in the presentation. Electricity use for the process end use was negligible and was not included in the figures.

The average electricity use by end use for these 12 installations and Fort Hood are as follows. HVAC, miscellaneous, and indoor lighting end uses consumed the most electricity, with 28,27 , and $26 \%$ of the total use, and $3.8,3.5$, and $3.3 \mathrm{kWh} / \mathrm{ft}^{2}$, respectively. Refrigeration, street lighting, exterior lighting, and cooking end uses consumed $7,7,3$, and $2 \%$ of the total electricity use, and $0.9,0.9,0.4$, and $0.3 \mathrm{kWh} / \mathrm{ft}^{2}$, respectively. 
Table 5-26. 1993 Electricity Consumption Estimates by End Use for 13 U.S. Army Installations

\begin{tabular}{|c|c|c|c|c|c|c|c|c|c|}
\hline \multirow{2}{*}{ Installation } & HVAC & Cook & Misc & Ref & Ex Lit & In Lit & Prcss & St Lit & Total \\
\hline & \multicolumn{9}{|c|}{ GWh } \\
\hline Fort Dix & 7.6 & 2.3 & 19.2 & 6.4 & 1.6 & 19.3 & 0.0 & 3.0 & 59.3 \\
\hline Fort Belvoir & 18.0 & 2.8 & 52.2 & 7.2 & 3.7 & 43.9 & 0.1 & 11.7 & 139.6 \\
\hline Fort Bragg & 66.4 & 10.4 & 103.1 & 30.5 & 9.8 & 110.1 & 0.2 & 32.0 & 362.5 \\
\hline Fort Benning & 74.7 & 6.1 & 54.3 & 18.2 & 4.6 & 48.0 & 0.1 & 11.9 & 217.8 \\
\hline Fort Polk . & 65.6 & 4.4 & 46.1 & 13.7 & 4.8 & 35.9 & 0.1 & 10.0 & 180.6 \\
\hline Fort Benjamin Harrison & 14.2 & 0.9 & 26.2 & 3.0 & -1.0 & 19.0 & 0.0 & 4.1 & 68.4 \\
\hline Fort Leonard Wood & 30.4 & 4.5 & 36.2 & 11.6 & 3.1 & 35.3 & 0.0 & 8.2 & 129.4 \\
\hline Fort Irwin & 20.4 & 1.9 & 19.0 & 5.6 & 2.1 & 15.8 & 0.0 & 4.5 & 69.4 \\
\hline Fort Sill & 54.7 & 3.7 & 35.7 & 9.8 & 2.6 & 39.5 & 0.1 & 7.2 & 153.3 \\
\hline Yuma Pg & 13.3 & 0.5 & 5.2 & 1.4 & 0.7 & 6.7 & 0.0 & 3.5 & 31.2 \\
\hline Fort Bliss & 24.9 & 4.3 & 48.2 & 12.3 & 4.0 & 49.8 . & 0.1 & 8.8 & 152.3 \\
\hline Fort Sam Houston & 53.5 & 2.9 & 35.2 & 7.3 & 2.4 & 35.4 & 0.0 & 8.9 & 145.6 \\
\hline \multirow[t]{2}{*}{ Fort Hood } & 145.8 & 6.8 & 64.2 & 21.1 & 6.4 & 70.7 & 0.2 & 18.1 & 333.3 \\
\hline & \multicolumn{9}{|c|}{$\mathrm{kWh} / \mathrm{ft}^{2}$} \\
\hline Fort Dix & 0.9 & 0.3 & 2.2 & 0.7 & 0.2 & 2.2 & 0.0 & 0.3 & 6.7 \\
\hline Fort Belvoir & 1.9 & 0.3 & 5.5 & 0.8 & 0.4 & 4.6 & 0.0 & 1.2 & 14.7 \\
\hline Fort Bragg & 2.6 & 0.4 & 4.0 & 1.2 & 0.4 & 4.3 & 0.0 & 1.3 & 14.2 \\
\hline Fort Benning & 3.9 & 0.3 & -2.8 & 0.9 & 0.2 & 2.5 & 0.0 & 0.6 & 11.3 \\
\hline Fort Polk & 3.9 & 0.3 & 2.8 & 0.8 & 0.3 & 2.1 & 0.0 & 0.6 & 10.8 \\
\hline Fort Benjamin Harrison & 3.1 & 0.2 & 5.7 & 0.7 & 0.2 & 4.1 & 0.0 & 0.9 & 14.9 \\
\hline Fort Leonard Wood & 2.7 & 0.4 & 3.2 & 1.0 & 0.3 & 3.1 & 0.0 & 0.7 & 11.5 \\
\hline Fort Irwin & 3.3 & 0.3 & 3.1 & 0.9 & 0.3 & 2.5 & 0.0 & 0.7 & 11.2 \\
\hline Fort Sill & 3.9 & 0.3 & 2.5 & 0.7 & 0.2 & 2.8 & 0.0 & 0.5 & 10.8 \\
\hline Yuma Pg & 10.2 & 0.4 & 4.0 & 1.1 & 0.5 & 5.2 & 0.0 & 2.7 & 24.0 \\
\hline Fort Bliss & 1.6 & 0.3 & 3.1 & 0.8 & 0.3 & 3.2 & 0.0 & 0.6 & 9.8 \\
\hline Fort Sam Houston & 5.8 & 0.3 & 3.8 & 0.8 & 0.3 & 3.8 & 0.0 & 1.0 & 15.8 \\
\hline \multirow[t]{2}{*}{ Fort Hood } & 5.7 & 0.3 & 2.5 & 0.8 & 0.3 & 2.8 & 0.0 & 0.7 & 13.1 \\
\hline & \multicolumn{9}{|c|}{$\%$ of Total } \\
\hline Fort Dix & 13 & 4 & 32 & 11 & 3 & 33 & 0 & 4 & 100 \\
\hline Fort Belvoir & 13 & 2 & 37 & 5 & 3 & 31 & 0 & 9 & 100 \\
\hline Fort Bragg & 18 & 3 & 28 & 8 & 3 & 30 & 0 & 10 & 100 \\
\hline Fort Benning & 34 & 3 & 25 & 8 & 2 & 22 & 0 & 6 & 100 \\
\hline Fort Polk & 36 & 2 & 26 & 8 & 3 & 20 & 0 & 5 & 100 \\
\hline Fort Benjamin Harrison & 21 & 1 & 38 & 4 & 1 & 28 & 0 & 7 & 100 \\
\hline Fort Leonard Wood & 23 & 3 & 28 & 9 & 2 & 27 & 0 & 8 & 100 \\
\hline Fort Irwin & 29 & 3 & 27 & 8 & 3 & 23 & 0 & 7 & 100 \\
\hline Fort Sill , & 36 & 2 & 23 & 6 & 2 & 26 & 0 & 5 & 100 \\
\hline Yuma Pg & 43 & 2 & 17 & 4 & 2 & 21 & 0 & -11 & 100 \\
\hline Fort Bliss & 16 & 3 & 32 & 8 & 3 & 33 & 0 & 5 & 100 \\
\hline Fort Sam Houston & 37 & 2 & 24 & 5 & 2 & 24 & 0 & 6 & 100 \\
\hline Fort Hood & 45 & 2 & 19 & 6 & 2 & 21 & 0 & 5 & 100 \\
\hline
\end{tabular}


Figure 5-2. 1993 Electricity Consumption Estimates by End Use for 13 U.S. Army Installations (GWh).

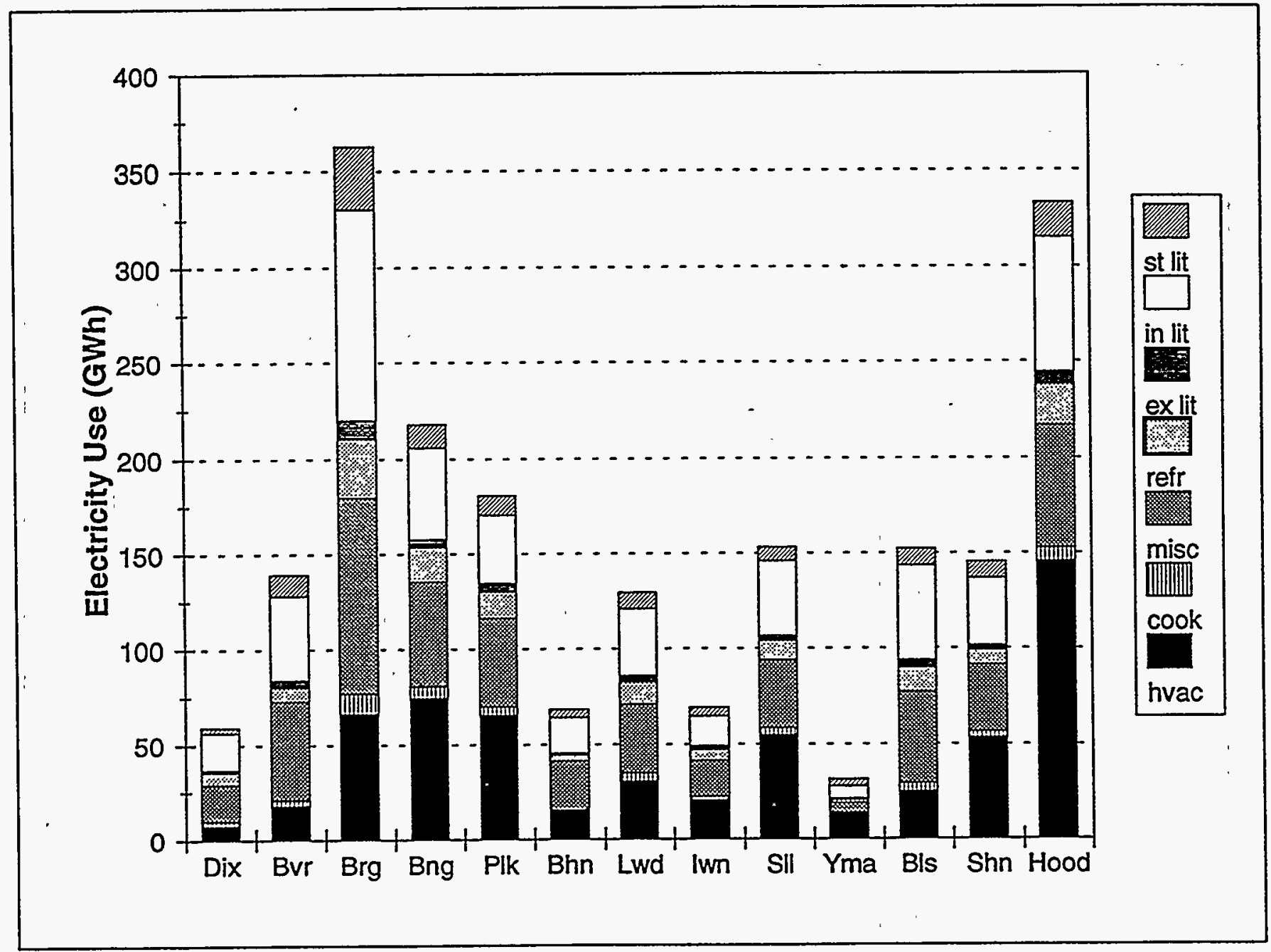


Figure 5-3. 1993 Electricity Consumption Estimates by End Use for 13 U.S. Army Installations $\left(\mathrm{kWh} / \mathrm{ft}^{2}\right)$.

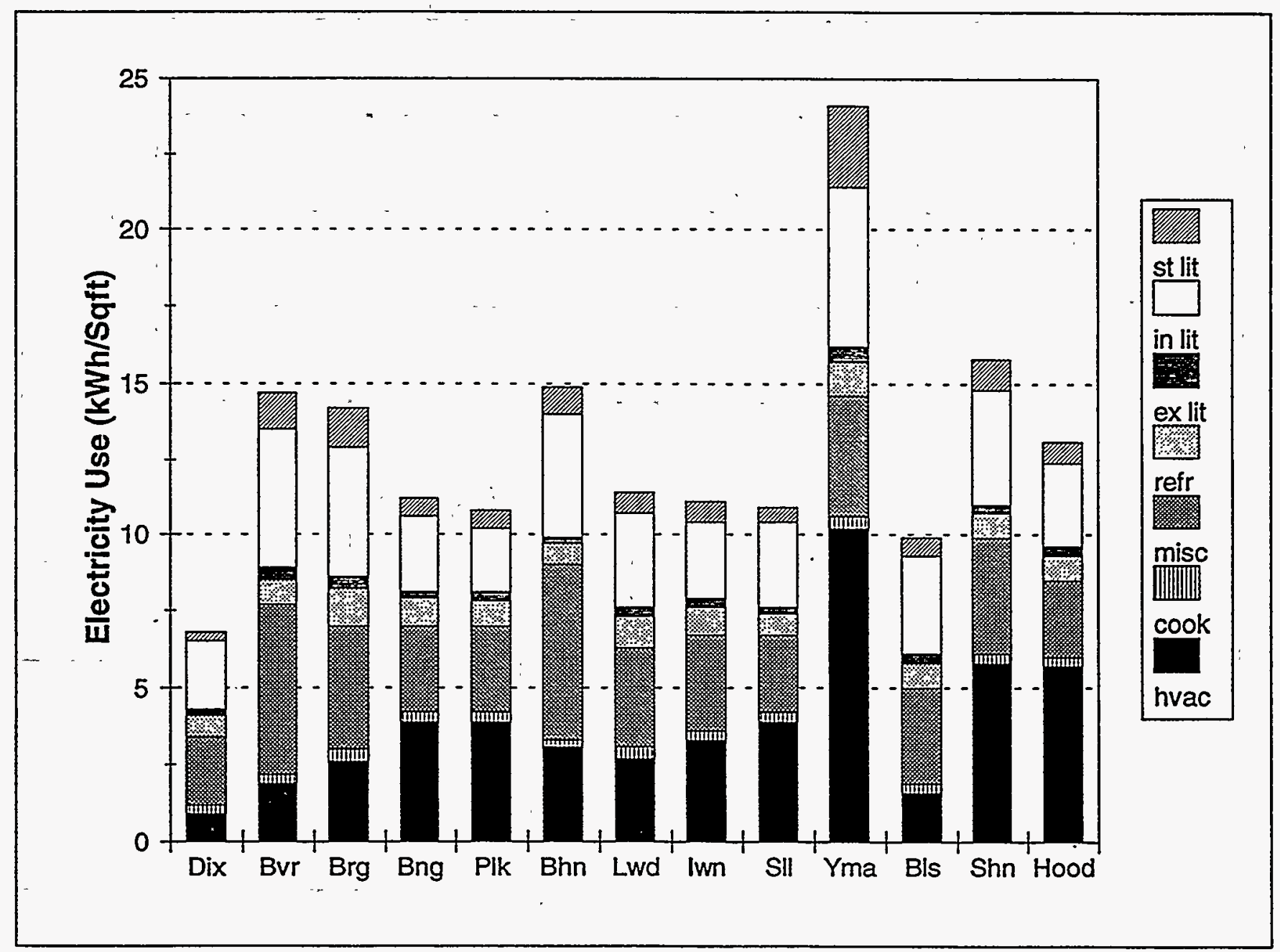


Figure 5-4. 1993 Electricity Consumption Estimates by End Use for 13 U.S. Army Installations (\% of Total).
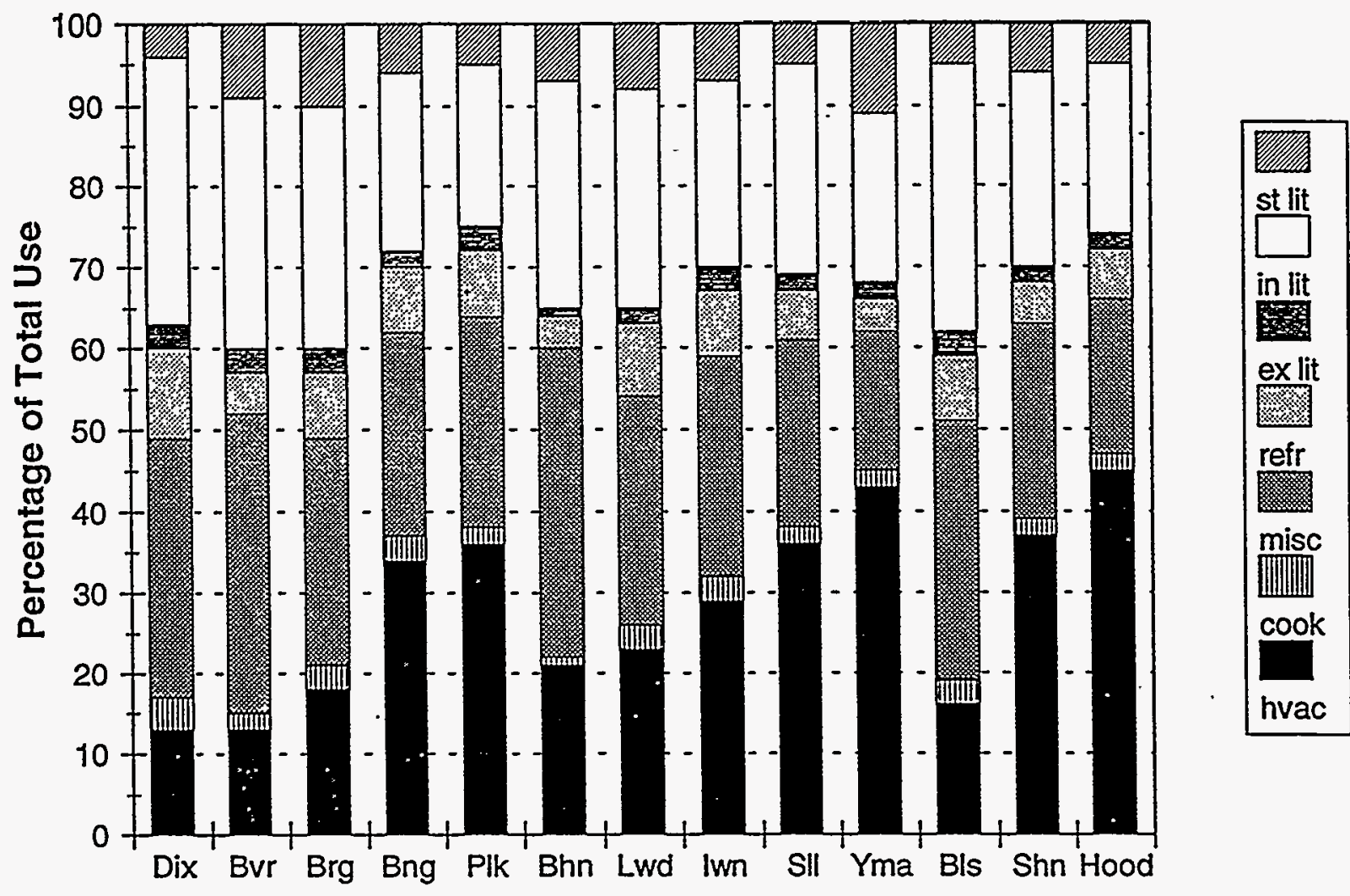
Figure 5-5. 1993 Electricity Consumption Estimates by End Use for 13 U.S. Army Installations, where minimum, maximum, $25 \%$ quartile, $75 \%$ quartile, mean, and median are shown $\left(\mathrm{kWh} / \mathrm{ft}^{2}\right)$.

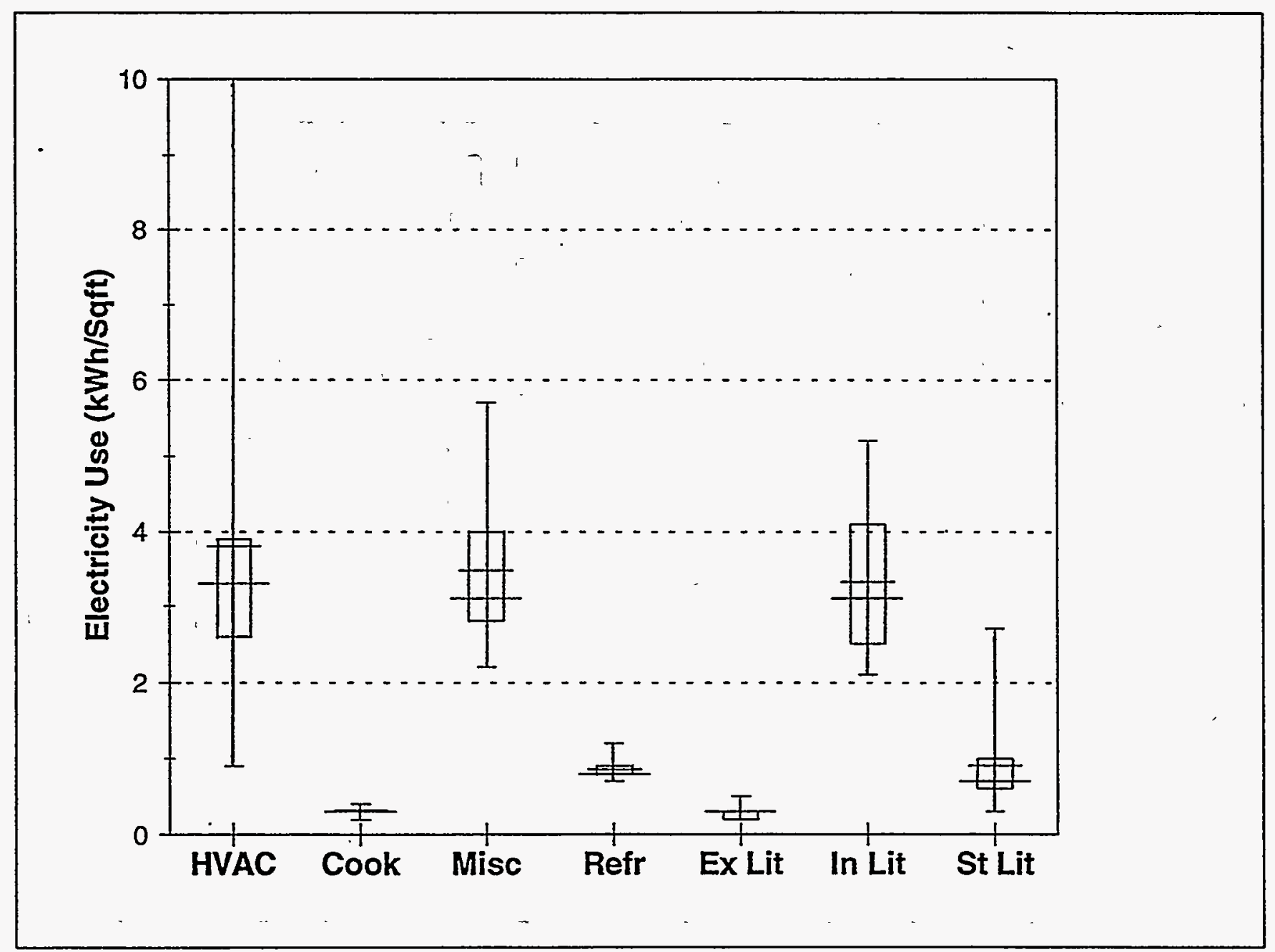


Figure 5-6. 1993 Electricity Consumption Estimates by End Use for 13 U.S. Army Installations, where minimum, maximum, $25 \%$ quartile, $75 \%$ quartile, mean, and median are shown (\% of Total).

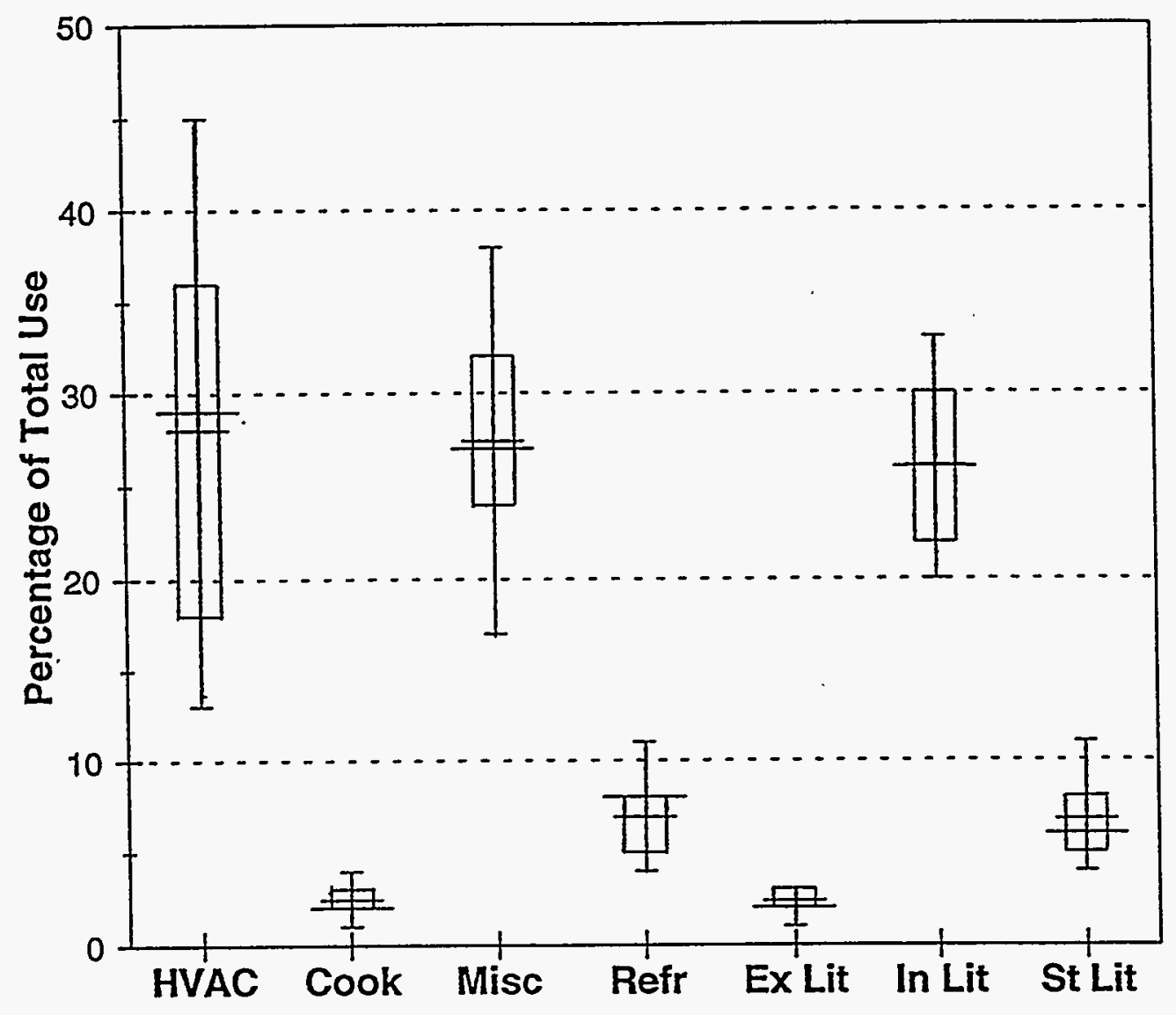


Figure 5-7. 1993 Electricity Consumption Estimates by End Use for Average of 13 U.S. Army Installations (\% of Total).

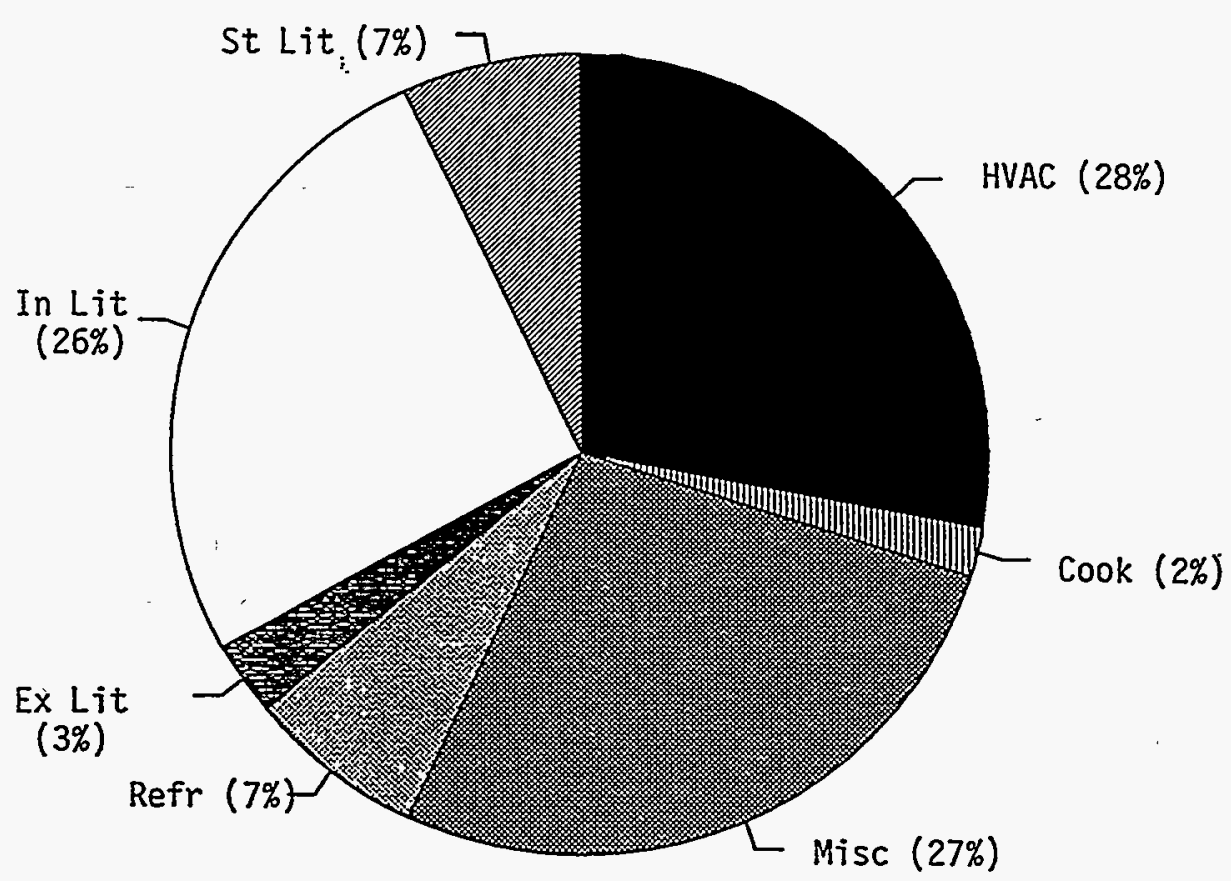




\section{Bibliography}

\section{Documents Referenced in Report}

Akbari, H., "Validation of an Algorithm to Disaggregate Whole-Building Hourly Electrical Load into End Uses," Energy the International Journal, 1996.

Akbari, H. and Konopacki, S., "End-use Energy Characterization and Conservation Potentials at DoD Facilities: An Analysis of Electricity Use at Fort Hood, Texas," Lawrence Berkeley National Laboratory Report LBL-36974, Berkeley, CA, 1995.

Building Energy Simulation Group (BESG), "Overview of the DOE-2 Building Energy Analysis Program, Version 2.1D," Lawrence Berkeley Laboratory Report LBL-19735, Rev.1, Berkeley, CA, 1990.

\section{Other Relevant Documents}

Akbari, H., Eto, J. H., Konopacki, S., Afzal, A., Rainer, L., and Heinemeier, K., "Integrated Estimation of Commercial Sector End-Use Load Shapes and Energy Use Intensities in the PG\&E Service Area," Lawrence Berkeley Laboratory Report LBL-34263, Berkeley, CA, 1993.

Akbari, H., Eto, J. H., Turiel, I., Heinemeier, K., Lebot, B., Nordman, B., and Rainer, L., "Integrated Estimation of Commercial Sector End-Use Load Shapes and Energy Use Intensities," Lawrence Berkeley Laboratory Report LBL-27512, Submitted to SCE and CEC, 1989.

Akbari, H., Heinemeier, K., Flora, D., and Le Coniac, P., "Analysis of Commercial Whole-Building 15Minute Electric Load Data," ASHRAE Transactions, 94(2), pp 855 - 871, 1988.

Akbari, H., Heinemeier, K., Le Coniac, P., and Flora, D., "An Algorithm to Disaggregate Commercial Whole-Building Electric Hourly Load into End Uses," Proceedings of ACEEE 1988 Summer Study on Energy Efficiency in Buildings, Vol 10, pp 13-26, Asilomar, CA.

Akbari, H. and Konopacki, S., Application of an End-Use Disaggregation Algorithm for Obtaining Building Energy-Use Data, Lawrence Berkeley National Laboratory LBL-38035, J. of Solar Energy Engineering, Berkeley, CA, 1996 (Submitted).

Akbari, H., Konopacki, S., Lister, L., and DeBaillie, L., Energy End-Use Characterization at Fort Hood, Texas, Lawrence Berkeley National Laboratory LBL-38037, 1996 ASHRAE Annual Meeting, San Antonio, TX.

Akbari, H., Rainer, L., and Eto, J. H., "Integrated Estimation of Commercial Sector End-use Load Shapes and Energy Use Intensities, Phase II," Lawrence Berkeley Laboratory Report LBL-30401, Submitted to CEC, 1991.

Akbari, H., Rainer, L., Heinemeier, K., Huang, J., and Franconi, E., "Measured Commercial Load Shapes and Energy Use Intensities and Validation of the LBL End-use Disaggregation Algorithm," Lawrence Berkeley Laboratory Report LBL-32193, Submitted to SCE and CIEE, 1992.

Akbari, H., Turiel, I., Eto, J. H., Heinemeier, K., Lebot, B., and Rainer, L., "A Review of Existing Commercial Energy Use Intensity and Load-Shapes Studies," Proceedings of the ACEEE 1990 Summer Study on Energy Efficiency in Buildings, Volume 3, p. 7, Asilomar, CA, 1990. also Lawrence Berkeley Laboratory Report LBL-29209, 1990.

Eto, J. H., Akbari, H., Pratt, R., and Braithwait, "End-Use Load Shape Data: Application, Estimation, and Collection," Proceedings of the ACEEE 1990 Summer Study on Energy Efficiency in Buildings, Volume 10, p.39, Asilomar, CA, 1990. 
Eto, J. H., Turiel, I., Akbari, H., Lebot, B., and Heinemeier, K., "An Investigation of the Use of Prototypes for Commercial Sector EUI Analysis," Proceedings of the ACEEE 1990 Summer Study on Energy Efficiency in Buildings, Volume 10, p. 29, Asilomar, CA, 1990.

Konopacki, S., DeBaillie, L., Akbari, H., and Lister, L., Electrical Energy and Cost Savings Potential at DoD Facilities, Lawrence Berkeley National Laboratory LBL-38036, 1996 ASHRAE Annual Meeting, San Antonio, TX. 